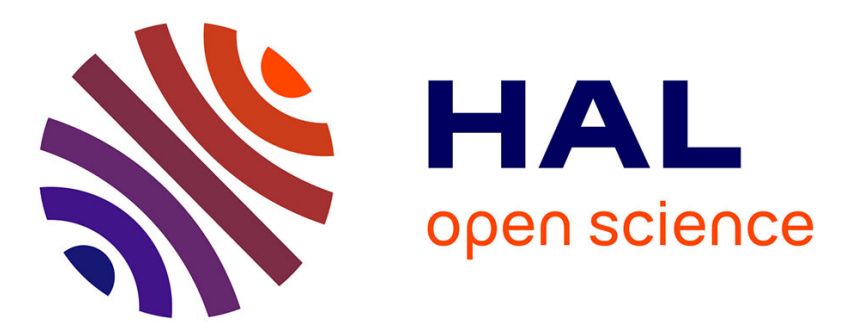

\title{
Tetralactam-Modified Gold Electrodes for Amperometric Detection of Acrylic Acid
}

Agnieszka Krajewska, Mario Smet, Wim Dehaen, Hanna Jadwiga Radecka

\section{To cite this version:}

Agnieszka Krajewska, Mario Smet, Wim Dehaen, Hanna Jadwiga Radecka. Tetralactam-Modified Gold Electrodes for Amperometric Detection of Acrylic Acid. Supramolecular Chemistry, 2009, 21 (06), pp.520-531. 10.1080/10610270802406587 . hal-00513537

\section{HAL Id: hal-00513537 https://hal.science/hal-00513537}

Submitted on 1 Sep 2010

HAL is a multi-disciplinary open access archive for the deposit and dissemination of scientific research documents, whether they are published or not. The documents may come from teaching and research institutions in France or abroad, or from public or private research centers.
L'archive ouverte pluridisciplinaire HAL, est destinée au dépôt et à la diffusion de documents scientifiques de niveau recherche, publiés ou non, émanant des établissements d'enseignement et de recherche français ou étrangers, des laboratoires publics ou privés. 


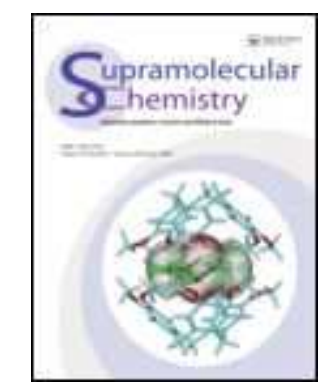

\section{Tetralactam-Modified Gold Electrodes for Amperometric Detection of Acrylic Acid}

\begin{tabular}{|c|c|}
\hline Journal: & Supramolecular Chemistry \\
\hline Manuscript ID: & GSCH-2008-0039.R1 \\
\hline Manuscript Type: & Full Paper \\
\hline $\begin{array}{r}\text { Date Submitted by the } \\
\text { Author: }\end{array}$ & 20-Jun-2008 \\
\hline Complete List of Authors: & $\begin{array}{l}\text { Krajewska, Agnieszka; Polish Academy of Sciences, Department of } \\
\text { Biosensors in Food } \\
\text { Smet, Mario; University of Leuven, Department of Chemistry } \\
\text { Dehaen, Wim; University of Leuven, Department of Chemistry } \\
\text { Radecka, Hanna; Polish Academy of Sciences, Department of } \\
\text { Biosensors in Food }\end{array}$ \\
\hline Keywords: & acrylic acid, tetralactam, OSWV, gold electrodes \\
\hline
\end{tabular}

\section{ऽ ScholarONE \\ Manuscript Central}


1

2

3

4

5

6

7

8

9

10

11

12

13

14

15

16

17

18

19

20

21

22

23

24

25

Supramolecular Chemistry

Vol. X, No. X, Month 200X, 000-000

\title{
Tetralactam-Modified Gold Electrodes for Amperometric Detection of Acrylic Acid
}

\author{
A. Krajewska ${ }^{\mathrm{a}}$, M. Smet ${ }^{\mathrm{b}}$, W. Dehaen ${ }^{\mathrm{b}}, \mathrm{H}$. Radecka $^{\mathrm{a}^{*}}$ \\ ${ }^{a}$ Institute of Animal Reproduction and Food Research, Polish Academy of Sciences, Tuwima 10, 10-747 \\ Olsztyn, Poland; ${ }^{b}$ Department of Chemistry, University of Leuven, Celestijnenlaan 200F B-3001, Leuven, Belgium
}

\begin{abstract}
The presence of toxic acrylamide in a wide range of food products such as potato crisps, French fries or bread has been confirmed by Swedish scientists from Stockholm University. The neurotoxicity and possible carcinogenicity of this compound and its metabolites compels us to control them by quantitative and qualitative assays.

Exposing acrylamide to $\mathrm{pH}$ extremes results in its hydrolysis to acrylic acid or its salt. In this work we present the use of gold electrodes coated with SAMs containing tetralactam molecules and its precursor as active elements for voltammetric detection of acrylic acid in water solution. The host molecules have been immobilized on the electrode surface by covalent Au-S bond or by embedment method into thiol layer via hydrophobic and van der Waals interactions. Interactions with analytes were confirmed by Osteryoung square wave voltammetry (OSWV).
\end{abstract}

Keywords: acrylic acid, tetralactam, OSWV, gold electrodes

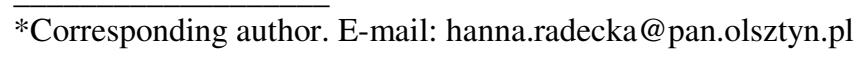




\section{Introduction}

Acrylamide is a well known neurotoxin and potential carcinogen [1, 2]. High levels of this compound have been found in potato chips, French fries and several other common foods [3-5]. The first such report was announced by scientists from Stockholm University in 2002 [3]. Acrylamide forms in the reaction between reducing sugars such as glucose and amino acid asparagine. The Millard reaction mechanism has been proposed to account for its formation in high starch foods during cooking at high temperature [6-8]. Investigation has shown that high temperature and long heat treatment result in higher acrylamide content [6]. Among analytical methods used to determine acrylamide levels, expensive and time-consuming chromatographic techniques such as GC-MS [9], GC-MS-MS [10], HPLC-MS [11] and LC-MS-MS [5] predominate. Preparation of samples from food involves extraction using water or methanol and the clean-up step typically consists of a combination of several solid-phase extractions. GC-MS often needs the additionally laborious bromination step to form more volatile acrylamide derivative and increase selectivity of determination. Only a few examples of using different techniques for detection of this toxic compound exist. Stobiecka and co-workers introduced a voltammetric sensor based on the reaction of hemoglobin with acrylamide [12]. This reaction leads to hemoglobin-acrylamide adducts formation that alters the electroactivity of hemoglobin. This biosensor showed good selectivity and sensitivity.

Exposing acrylamide to $\mathrm{pH}$ extremes results in its hydrolysis to acrylic acid or its salt. The most frequently used methods of acrylic acid determination also include GC [13] and HPLC [14]. Ignatov and coworkers prepared a biosensor in which respiratory activity of microbial cells was used for detection of acrylamide and acrylic acid [15]. Kleefisch and co-workers reported a sensor in which acrylamide and acrylic acid was detected at a gas-solid interface using an 'electronic nose'-type quartz crystal microbalance (QCM) sensor covered with a tetralactam active layer [16]. This system had not previously been tested at waterorganic interface.

Tetralactams belong to a wide group of neutral compounds able to complex anions by hydrogen bond formation $[17,18]$. These macrocycles have been used recently as the macrocyclic host for detection of carbonyl compounds. Hunter showed that such a macrocycle can complex $p$-benzoquinone and the recognition process can be achieved via a combination of $\pi-\pi$ interaction and four hydrogen bond formations to the quinone oxygens. This phenomenon was confirmed by an ${ }^{1} \mathrm{H}$ NMR experiment performed in $\mathrm{CDCl}_{3}$ [19]. A similar experiment performed in $\mathrm{CD}_{2} \mathrm{Cl}_{2}$ and mixture of $\mathrm{CD}_{2} \mathrm{Cl}_{2} / \mathrm{CD}_{3} \mathrm{OD}$ at a $4: 1$ ratio showed interaction of these compounds with $\mathrm{Br}^{-}, \mathrm{Cl}^{-}$, weaker with $\mathrm{NO}_{3}{ }^{-}$and $\mathrm{AcO}^{-}$[20]. Tetralactam has been used in an electronic nose sensor to create a sensitive and selective active layer on the gold surface of quartz crystal 
electrodes and detect apple ester, 2-hexanal, s-limonesse and 2-heptanon [21, 22]. Hydrogen bonds formation and $\pi-\pi$ interaction were responsible for the formation of catenate and rotaxanes. Their synthesis was based on the action of supramolecular nucleophile that is formed from the molecular recognition of an anionic stopper by a tetralactam wheel [23-25].

Similar macrocycles containing pyridine fragments showed binding affinities for a diamide guest $\left(\mathrm{Et}_{2} \mathrm{NC}(\mathrm{O})\left(\mathrm{CH}_{2}\right)_{4} \mathrm{C}(\mathrm{O}) \mathrm{NEt}_{2}\right)$. These interactions were investigated also in $\mathrm{CDCl}_{3}$ by an ${ }^{1} \mathrm{H}$ NMR titration experiment [26].

In this paper we present the use of gold electrodes coated with SAMs containing tetralactam macrocycle and its acyclic derivative (Fig. 1) as active elements for voltammetric detection of acrylic acid in water solution. The host molecules have been immobilized on an electrode surface by covalent Au-S bond or by embedment method into the thiol layer via hydrophobic and van der Waals interactions. Influence of modification type on electrodes sensitivity has been investigated.

\section{Experimental}

\section{Reagents and materials}

1-Dodecanethiol (DDT), $\left[\mathrm{Ru}\left(\mathrm{NH}_{3}\right)_{6}\right] \mathrm{Cl}_{3}$, acrylic acid were purchased from Aldrich Chemie (Germany). Potassium nitrate was purchased from POCh (Gliwice, Poland). Aqueous solution were prepared with deionized water $\left(18.2 \mathrm{M} \Omega \mathrm{cm}\right.$ resistivity) obtained with a Simplicity ${ }^{\circledR} 185$ Water System (Millipore, Molsheim, France).

\section{Synthesis of receptors}

Receptors 1, 2 and 3 have been synthesized in the Department of Chemistry, University of Leuven (Fig. 2). Dodecyloxyisophthaloyl dichloride 1 [27], bisamine 2 [23], monoBoc derivative 6 [28] and benzyloxyisophthaloyl dichloride $\mathbf{9}$ [29] were obtained according to literature procedures. All other reagents were obtained commercially and used as received. NMR spectra were recorded on a Bruker Avance 300 or 400.

5-Dodecyloxyisophthaloyl bis(diamine) $\mathbf{3}$ (receptor 3) 
Diamine 2 (21.0 g; $65.2 \mathrm{mmol})$ was dissolved in $\mathrm{CH}_{2} \mathrm{Cl}_{2}(100 \mathrm{ml})$ and triethylamine $(3.2 \mathrm{~mL})$ was added. 5Dodecyloxyisophthaloyl dichloride $(4.50 \mathrm{~g} ; 11.6 \mathrm{mmol}) \mathbf{1}$ was similarly dissolved in $\mathrm{CH}_{2} \mathrm{Cl}_{2}(100 \mathrm{~mL})$ and added dropwise to the diamine solution during $2 \mathrm{~h}$ with stirring under argon. The solvent was evaporated under reduced pressure and the dissolved residue was purified by column chromatography on silica with $\mathrm{CH}_{2} \mathrm{Cl}_{2}$ /ethyl acetate $7: 1$ as the eluent yielding $3(2.9 \mathrm{~g} ; 26.3 \%) .{ }^{1} \mathrm{H} \mathrm{NMR}\left(\delta, \mathrm{CDCl}_{3}, 400 \mathrm{MHz}\right) 7.97(\mathrm{~s}, 1 \mathrm{H})$, 7.57 (s, 2H), 7.43 (s, 2H), 7.00 (s, 4H), 6.85 (s, 4H), 4.07 (t, 2H), 3.45 (s br, 4H), 2.19 (m, br, 16H), 2.14 (s, 12H), $1.81(\mathrm{~m}, 2 \mathrm{H}), 1.54-1.47(\mathrm{~m}, 16 \mathrm{H}), 1.25-1.27$ (m, 20H), 0.87 (t, 3H). ESI MS (m/z) $960 \mathrm{MH}^{+}$.

\section{Macrocyclic tetralactam 5 (receptor 2)}

Diamine 3 (0.91 g; $0.95 \mathrm{mmol})$ and $\mathrm{Et}_{3} \mathrm{~N}(0.29 \mathrm{~g} ; 2.8 \mathrm{mmol})$ were dissolved in $\mathrm{CH}_{2} \mathrm{Cl}_{2}(20 \mathrm{~mL})$. Isophthaloyl dichloride 4 (0.19 g; $0.95 \mathrm{mmol})$ was dissolved in a separate volume of $\mathrm{CH}_{2} \mathrm{Cl}_{2}(20 \mathrm{~mL})$. Both solutions were slowly added with an infusion pump during $4 \mathrm{~h}$ to a stirred volume of $\mathrm{CH}_{2} \mathrm{Cl}_{2}(1.2 \mathrm{~L})$ at room temperature. After complete addition, stirring was continued for $10 \mathrm{~h}$ at room temperature, after which the solvent was evaporated under reduced pressure. The residue was subjected to column chromatography on $\mathrm{SiO}_{2}$ with $\mathrm{CH}_{2} \mathrm{Cl}_{2}$ /ethyl acetate $4: 1$ as the eluent yielding 5 as a white solid in $16 \%$ yield. ${ }^{1} \mathrm{H} \mathrm{NMR}\left(\delta, \mathrm{CDCl}_{3} / \mathrm{CH}_{3} \mathrm{OD}\right.$ 19:1, $300 \mathrm{MHz}) 8.31$ (m, br, 1H), 8.16-8.13 (m, br, 2H), 7.85 (s, br, 1H), 7.66-7.65 (m, br, 3H), 6.99 (s, 8H), 4.09 (t, 2H), 2.45 (m,br, 4H), 2.34 (m, br, 4H), 2.27 (m, br, 16H), $2.17(\mathrm{~s}, 12 \mathrm{H}), 1.82(\mathrm{~m}, 2 \mathrm{H}), 1.65$ (m, br, 4H), $1.52(\mathrm{~m}, \mathrm{br}, 4 \mathrm{H}), 1.27-2.25(\mathrm{~m}, \mathrm{br}, 20 \mathrm{H}), 0.88(\mathrm{t}, 3 \mathrm{H})$. ESI MS (m/z) $1089 \mathrm{MH}^{+}$.

\section{Boc-protected bisamide 7}

Mono-boc-protected derivative $6(2.1 \mathrm{~g} ; 5.0 \mathrm{mmol})$ and $\mathrm{Et}_{3} \mathrm{~N}(0.50 \mathrm{~g} ; 5.0 \mathrm{mmol})$ were dissolved in $\mathrm{CH}_{2} \mathrm{Cl}_{2}(60$ $\mathrm{mL})$ and added dropwise over $30 \mathrm{~min}$ to a stirred solution of isophthaloyl dichloride 4 (0.50 g; $2.5 \mathrm{mmol})$ in $\mathrm{CH}_{2} \mathrm{Cl}_{2}(100 \mathrm{~mL})$ at room temperature. After complete addition, the solution was stirred for another $2 \mathrm{~h}$ and the solvent was evaporated under reduced pressure. The target bisamide 7 was obtained after column chromatography on $\mathrm{SiO}_{2}$ with $\mathrm{CH}_{2} \mathrm{Cl}_{2}$ /ethyl acetate $4: 1$ as the eluent as a white solid in $76 \%$ yield. ${ }^{1} \mathrm{H}$ NMR $\left(\delta, \mathrm{CDCl}_{3}, 300 \mathrm{MHz}\right) 8.52(\mathrm{~s}, 1 \mathrm{H}), 8.22(\mathrm{~m}, \mathrm{br}, 2 \mathrm{H}), 7.74(\mathrm{~m}, \mathrm{br}, 2 \mathrm{H}), 6.69(\mathrm{~s}, 4 \mathrm{H}), 6.96(\mathrm{~s}, 4 \mathrm{H}), 6.81(\mathrm{~s}, \mathrm{br}$, 1H), 5.97 (s, br, 2H), 2.19 (m,br, 16H), 2.06 (s, 12H), 1.55-1.39 (m, br, 16H), 1.39 (s, 18H). ESI MS (m/z) $975 \mathrm{MH}^{+}$. 


\section{Bisamine 8}

To bisamide 7 (1.95 g; $2.0 \mathrm{mmol}) \mathrm{CH}_{2} \mathrm{Cl}_{2}(5 \mathrm{~mL})$ and trifluoroacetic acid (5 mL) were added and the resulting mixture was stirred for $1 \mathrm{~h}$ at room temperature. The mixture was poured into an aqueous saturated $\mathrm{NaHCO}_{3}$ solution $(100 \mathrm{~mL})$ and the resulting suspension was extracted with $\mathrm{CH}_{2} \mathrm{Cl}_{2}(3 \times 70 \mathrm{~mL})$. The combined organic layers were dried over $\mathrm{MgSO}_{4}$ and the solvent was evaporated under reduced pressure, yielding bisamine $\mathbf{8}$ as a white solid in $83 \%$ yield. The spectral data were found to be identical to published data [23].

\section{Benzyl protected macrocyclic tetralactam 10}

Bisamine 8 (1.2 g; $1.6 \mathrm{mmol})$ and $\mathrm{Et}_{3} \mathrm{~N}(0.48 \mathrm{~g} ; 4.8 \mathrm{mmol})$ were dissolved in $\mathrm{CH}_{2} \mathrm{Cl}_{2}(15 \mathrm{~mL})$ and dicarbonyl dichloride 9 (0.49 g; $1.6 \mathrm{mmol})$ was dissolved in another volume of $\mathrm{CH}_{2} \mathrm{Cl}_{2}(15 \mathrm{~mL})$. Both solutions were added dropwise at room temperature to a stirred volume of $\mathrm{CH}_{2} \mathrm{Cl}_{2}(1.5 \mathrm{~L})$ over $4 \mathrm{~h}$. Stirring was continued for $10 \mathrm{~h}$ at room temperature. The solvent was evaporated under reduced pressure and the macrocyclic tetralactam 10 was obtained as a white solid after column chromatography on $\mathrm{SiO}_{2}$ with $\mathrm{CH}_{2} \mathrm{Cl}_{2}$ /ethyl acetate 4:1 as the eluent $21 \%$ yield. ${ }^{1} \mathrm{H}$ NMR $\left(\delta, \mathrm{CDCl}_{3}, 300 \mathrm{MHz}\right) 8.37(\mathrm{~s}, 1 \mathrm{H}), 8.16(\mathrm{~d}, 2 \mathrm{H}), 7.94(\mathrm{~s}, 1 \mathrm{H}), 7.83-7.77$ $(\mathrm{m}, 4 \mathrm{H}), 7.71(\mathrm{~s}, 2 \mathrm{H}), 7.45-7.32(\mathrm{~m}, 5 \mathrm{H}), 6.98(\mathrm{~s}, 8 \mathrm{H}), 5.18(\mathrm{~s}, 2 \mathrm{H}), 2.78(\mathrm{~s}, 6 \mathrm{H}), 2.53(\mathrm{~s}, 6 \mathrm{H}), 2.30-2.33(\mathrm{~m}$, $6 \mathrm{H}), 2.16(\mathrm{~s}, 8 \mathrm{H}), 1.62-1.51(\mathrm{~m}, 12 \mathrm{H})$. ESI MS (m/z) $1033.6 \mathrm{MNa}^{+}$.

\section{Undecenyloxy substituted macrocyclic tetralactam 12}

Benzyl protected tetralactam $10(100 \mathrm{mg} ; 0.099 \mathrm{mmol})$ was dissolved in a 1:1 mixture of $\mathrm{CHCl}_{3}$ and ethanol (12 mL). Palladium on carbon (10\%) (0.5 g) was added and the resulting suspension was shaken vigorously for $15 \mathrm{~h}$ under hydrogen atmosphere. The suspension was filtered over celite and the solids were washed with ethanol $(2 \times 5 \mathrm{~mL})$. The combined filtrates were evaporated under reduced pressure and the residue containing phenol 11 was dissolved in DMF (10 mL). 11-Undecenyl bromide (46 mg; $0.20 \mathrm{mmol})$ and $\mathrm{K}_{2} \mathrm{CO}_{3}(28 \mathrm{mg}$; $0.20 \mathrm{mmol}$ ) were added and the resulting suspension was heated under continuous stirring at $80^{\circ} \mathrm{C}$ under argon atmosphere. After cooling to room temperature, the solvent was evaporated under reduced pressure and $\mathrm{CH}_{2} \mathrm{Cl}_{2}(10 \mathrm{~mL})$ and water $(10 \mathrm{~mL})$ were added to the residue. After vigorous shaking, the organic layer was separated, dried over $\mathrm{MgSO}_{4}$ and evaporated under reduced pressure. The title compound 12 was obtained as a white solid after column chromatography over $\mathrm{SiO}_{2}$ with $\mathrm{CH}_{2} \mathrm{Cl}_{2}$ /ethyl acetate 4:1 as the eluent in $72 \%$ yield. ${ }^{1} \mathrm{H}$ NMR $\left(\delta, \mathrm{CDCl}_{3} / \mathrm{CH}_{3} \mathrm{OD} 19: 1,300 \mathrm{MHz}\right) 8.36(\mathrm{~s}, 1 \mathrm{H}), 8.14(\mathrm{~d}, 2 \mathrm{H}), 7.86(\mathrm{~s}, 1 \mathrm{H}), 7.66(\mathrm{~s}, 2 \mathrm{H}), 7.64$ $(\mathrm{t}, 1 \mathrm{H}), 6.99(\mathrm{~s}, 8 \mathrm{H}), 5.82-5.71(\mathrm{~m}, 1 \mathrm{H}), 5.01-4.90(\mathrm{~m}, 2 \mathrm{H}), 4.09(\mathrm{t}, 2 \mathrm{H}), 2.33-2.03(\mathrm{~m}, 32 \mathrm{H}), 1.81(\mathrm{~m}, 4 \mathrm{H})$, 1.65-1.52 (m, 12H), 1.30-1.32 (m, 12H). ESI MS (m/z) $1072 \mathrm{MH}^{+}$. 


\section{Thioacetate 13}

Undecenyloxy derivative $\mathbf{1 2}$ (80 mg; $0.075 \mathrm{mmol}$ ) was dissolved in a 1:1 mixture of $\mathrm{CH}_{2} \mathrm{Cl}_{2}$ and methanol (50 $\mathrm{mL})$. Thioacetic acid $(57 \mathrm{mg} ; 0.75 \mathrm{mmol})$ and AIBN $(2 \mathrm{mg})$ were added and the resulting solution was irradiated at room temperature with a UV lamp ( $375 \mathrm{~nm}, 50$ Watt) under argon atmosphere for $12 \mathrm{~h}$. The solvent was evaporated under reduced pressure and the residue was dissolved in a 9:1 mixture of $\mathrm{CH}_{2} \mathrm{Cl}_{2} /$ methanol (approximately $0.5 \mathrm{~mL}$ ). This solution was added drop wise to a stirred volume of diisopropyl ether $(20 \mathrm{~mL})$. The precipitate was filtered and washed with diisopropyl ether $(2 \times 5 \mathrm{~mL})$ and dried in vacuum, yielding the title compound $\mathbf{1 3}$ in $86 \%$ yield. ${ }^{1} \mathrm{H}$ NMR $\left(\delta, \mathrm{CDCl}_{3}, 300 \mathrm{MHz}\right) 8.21$ (tr, br, $1 \mathrm{H}), 8.14(\mathrm{~d}, \mathrm{br}, 2 \mathrm{H}), 8.13(\mathrm{~d}, \mathrm{~b}, 2 \mathrm{H}), 7.72$, s, br, 1H), $7.66(\mathrm{~m}, \mathrm{~b}, 3 \mathrm{H}), 7.31(\mathrm{~s}, 2 \mathrm{H}), 6.97(\mathrm{~s}, 8 \mathrm{H}), 4.10$ (t, br, $2 \mathrm{H}), 2.85(\mathrm{t}, 2 \mathrm{H}), 2.30-2.28(\mathrm{~m}, \mathrm{br},+\mathrm{s}, 11 \mathrm{H}), 2.18-2.16(\mathrm{~s}, 16 \mathrm{H}), 1.86-1.82(\mathrm{~m}, \mathrm{br}, 4 \mathrm{H}), 1.67-1.64(\mathrm{~m}, \mathrm{br}$, $8 \mathrm{H}), 1.56-1.53(\mathrm{~m}, \mathrm{br}, 14 \mathrm{H}), 1.30-1.26(\mathrm{~m}, \mathrm{br}, 12 \mathrm{H})$. ESI MS (m/z) $1150 \mathrm{MH}^{+}$.

\section{Receptor 1 (14)}

Thioacetate 13 (50 mg; $0.044 \mathrm{mmol})$ was dissolved in a 2:1 mixture of THF and methanol $(5 \mathrm{~mL})$. The resulting solution was placed in an air tightvial closed with a septum. Argon was bubbled through the solution for 15 minutes via a syringe to remove oxygen. An aqueous solution of $\mathrm{NaOH}(1 \mathrm{~mL}, 1 \mathrm{M})$ was added via a syringe while keeping the reaction mixture under argon. The mixture was left for $10 \mathrm{~h}$ at room temperature, after which diluted $\mathrm{HCl}$ was added $(1.1 \mathrm{~mL}, 1 \mathrm{M})$ via a syringe. The solvents were evaporated under reduced pressure and the residue was treated with a 19:1 mixture of $\mathrm{CH}_{2} \mathrm{Cl}_{2}$ and methanol (approximately $2 \mathrm{~mL}$ ) to dissolve the organic material. The resulting solution was filtered and the filtrate was added drop wise to a stirred volume of diethyl ether $(10 \mathrm{~mL})$ to precipitate $\mathbf{1 4}$ which was collected by filtration, washed with diethyl ether $(2 \times 2 \mathrm{~mL})$ and obtained as a white solid in $45 \%$ yield. ${ }^{1} \mathrm{H}$ NMR $\left(\delta, \mathrm{CDCl}_{3} / \mathrm{CH}_{3} \mathrm{OH} 19: 1,300\right.$ MHz) 8.30 (s, br, 2H), 8.16 (s, 8H), 8.09 (s, br 4H), 7.82 (t, br, 2H), 7.65 (tr + d,br, 6H), 6.98 (s, 16H), 4.08 (t, br, $4 \mathrm{H}), 2.68(\mathrm{t}, 4 \mathrm{H}), 2.34-2.32(\mathrm{~m}, \mathrm{br}, 16 \mathrm{H}), 2.17-2.15(\mathrm{~m} \mathrm{br}+\mathrm{s}, 40 \mathrm{H}), 1.86-1.82(\mathrm{~m}, \mathrm{br}, 8 \mathrm{H}), 1.66-1.63(\mathrm{~m}$, br, $16 \mathrm{H}), 1.49-1.28(\mathrm{~m}, \mathrm{br}, 44 \mathrm{H})$. ESI MS (m/z) $1129\left[(\mathrm{MNa})_{2}\right]^{2+}$.

\section{Preparation of working electrodes}

Gold disk electrodes ( $2 \mathrm{~mm}^{2}$ area, Bioanalytical Systems (BAS) West Lafayette, Indiana, USA) were used for all experiments. Before modifications the electrodes were cleaned mechanically by polishing with 
wet 0.3 and $0.05 \mu \mathrm{m}$ alumina slurry (Alpha and Gamma Micropolish; Buehler, Lake Bluff, Illinois, USA) on a microcloth pad (BAS) and in a sonicator (30 sec.), then electrochemically by dipping in $0.5 \mathrm{M} \mathrm{KOH}$ solution and sweeping the potential between $-400 \mathrm{mV}$ and $-1200 \mathrm{mV}$ (versus a $\mathrm{Ag} / \mathrm{AgCl}$ reference electrode) with a | scan rate of $100 \mathrm{mVs}^{-1}$ till cyclic voltammograms no longer changed. The stop potential was $-400 \mathrm{mV}$.

\section{Modification of electrodes}

\section{Covalent modification}

Directly after cleaning electrodes were soaked in $0.1 \mathrm{mM}$ bis(tetralactam) disulphide solution (receptor 1) in ethanol/chloroform mixture $(1 / 1 \mathrm{v} / \mathrm{v})$ containing $1 \mathrm{mM}$ dodecanethiol at room temperature for $30 \mathrm{~min}$. Then after washing with ethanol and water the electrodes were stored in $0.01 \mathrm{M} \mathrm{KNO}_{3}$ at room temperature until use.

\section{Embedment modification}

Directly after cleaning, the electrodes were soaked in $0.01 \mathrm{mM}$ dodecanethiol solution in ethanol at room temperature for $30 \mathrm{~min}$. After washing with ethanol the electrodes were soaked in $1 \mathrm{mM}$ solution of receptor 2 or 3 in ethanol for $12 \mathrm{~h}$. Then after washing with ethanol and water the electrodes were stored in $0.01 \mathrm{M}$ $\mathrm{KNO}_{3}$ at room temperature until use.

Before measuring, modified electrodes were stored in a solution containing $0.01 \mathrm{M} \mathrm{KNO}_{3}, \mathrm{pH}=5.0$ for at $\underline{\text { least one day for conditioning. }}$

\section{Electrochemical measurement}

All electrochemical measurements were performed with a potentiostat-galvanostat AutoLab (Eco Chemie, Utrecht, Netherlands) with a three-electrode configuration. Potentials were measured versus the $\mathrm{Ag} / \mathrm{AgCl}$ reference electrode obtained from Bioanalytical Systems (BAS) West Lafayette, Indiana, USA. $\underline{\mathrm{Ag} / \mathrm{AgCl} \text { wire was placed in a glass tube filled with } 3 \mathrm{M} \mathrm{NaCl} \text {. The tube was closed with a vycor plug to }}$ protect the inner solution from direct contact with the sample solution. A platinum wire was used as the auxiliary electrode Cyclic voltammetry $(\mathrm{CV})$ was performed and potential was cycled from $+50 \mathrm{mV}$ to -500 Deleted: and a platinum wire was used $\mathrm{mV}$ for $\underline{1.0 \times 10^{-4} \mathrm{M}}\left[\mathrm{Ru}\left(\mathrm{NH}_{3}\right)_{6}\right] \mathrm{Cl}_{3}$ with a scan rate of $500 \mathrm{mVs}^{-1}$. Osteryoung square-wave voltammetry 
(OSWV) was performed in the same potential range with a step potential of $5 \mathrm{mV}$, a square-wave frequency of $100 \mathrm{~Hz}$, and amplitude of $25 \mathrm{mV}$. The dependence of the sensor responses on the concentration of analytes was expressed as the currents at the peak potential in OSWVs for $\left[\mathrm{Ru}\left(\mathrm{NH}_{3}\right)_{6}\right]^{3+}$ measured in a solution containing $0.01 \mathrm{M} \mathrm{KNO}_{3}$. Electrochemical impedance spectroscopy (EIS) was performed within the frequency range of $0.1 \mathrm{~Hz}$ to $10 \mathrm{kHz}$ at the formal potential of the redox couple $\left[\mathrm{Ru}\left(\mathrm{NH}_{3}\right)_{6}\right]^{2+/ 3+}(-0.2 \mathrm{~V})$ with ac amplitude of $10 \mathrm{mV}$.

\section{Results and Discussion}

\section{Synthesis of receptors}

An open chain bisamine 3 (receptor 3) was synthesized by reaction of dodecyloxyisophthaloyl dichloride 1 [27] with a large excess of bisamine 2 [23] (Fig. 2). Bisamine 3 was then cyclized to receptor 2 under high dilution conditions by reaction with isophthaloyl dichloride (4). For the synthesis of receptor 1, we first started the preparation of bisamine $\mathbf{8}$ on the basis of the literature [23]. However, it was found that largescale preparation of the latter compound proceeded more conveniently via the protected precursor 7, which was readily obtained by the reaction of equivalent amounts of isophthaloyl dichloride (4) and the monoprotected derivative $\mathbf{6}$ [28]. After deprotection, the bisamine $\mathbf{8}$ was allowed to react with benzyloxyisophthaloyl dichloride 9 [29] under high dilution conditions, yielding macrocyclic lactam 10. Hydrogenolytic removal of the benzyl group followed by Williamson etherification afforded the alkenylsubstituted analog 12 via intermediate phenol 11 - which was not isolated. After the radical addition of thioacetic acid, thioester 13 was isolated which, upon smooth basis hydrolysis in the presence of oxygen, gave rise to disulfide 14 or receptor 1 .

\section{Formation and characteristics of tetralactam SAMs}

Our paper presents two methods of immobilization of SAMs on gold electrode surfaces. The covalent method of modification involved one step in which 1-dodecanethiol and bis(tetralactam) molecules (receptor 1, Fig. 1) mixed in one solution were immobilized simultaneously on gold. Such a prepared mixed monolayer consisted of ionophore molecules covalently bonded to the electrode surface and dedecanethiol molecules, This procedure was used to prepare a dense monomolecular layer and avoid a pinholes formation. 
Dodecanethiol was chosen because of its ability to create a well-ordered monolayer and serve as an inert background for receptor molecules. Chain lengths of receptor tetralactam and dodecanethiol were similar, which helps create the ordered monolayer.

The embedment method involved two steps. Firstly, electrodes were modified only by 1-dodecanethiol to form a homogenous liphophilic monolayer on the surface. Then the macrocycle possessed one liphophilic side chain (receptor 2 or 3, Fig. 1) and was immobilized via hydrophobic and van der Waals interactions [30,31]. The layer formed by this procedure was rather bimolecular.

The monolayer prepared by the covalent method was better stabilized than that prepared by embedment. The first method assumed the creation of a covalent bond, but hydrophobic interactions between $\underline{\text { liphophilic side chain of the ionophore and liphophilic chains of 1-dodecanethiol also play some role in SAM }}$ stabilization. We found that electrodes modified by this method are stable during CV measurements performed in the wide potential window $(-500$ to $+50 \mathrm{mV})$. Mirsky and co-workers [32] postulated desorption of alkanethiol monolayer at electrode potentials -300 and $-600 \mathrm{mV}$ in the absence of alkanethiol in the bulk solution at $\mathrm{pH}=5.7$. The loss of monolayer stability was observed when negative potential was applied for longer than $15 \mathrm{~min}$. In our work negative potential was also applied to the modified electrodes but time of exposure was considerable lower: less than one minute in the case of $\mathrm{CV}$ (scan rate CV $500 \mathrm{mV} / \mathrm{s}$ ) and OSWV (step potential $5 \mathrm{mV}$, frequency $100 \mathrm{~Hz}$ ) and about $3 \mathrm{~min}$. in the case of impedance measurement. Because of this we did not observe any influence of negative potential applying and monolayer stability was kept.

In the case of embedment modification receptor molecules are bound to the electrode surface by weaker forces than in the case of covalent immobilization, but references $[30,31]$ give examples of using the same procedure to obtain stable and reproducible SAMs.

Both modification procedures were monitored with OSWV. In order to display the role of tetralactam host in SAMs the gold electrodes modified only with 1-dodecanethiol was used. These electrodes were measured with cyclic voltammetry (CV) and Osteryoung square wave voltammetry (OSWV) with $\left[\mathrm{Ru}\left(\mathrm{NH}_{3}\right)_{6}\right]^{3+}$ as redox marker. Obtained voltammograms were compared with results obtained for electrodes coated additionally with tetralactam by both methods of modification (Fig. 1 supplementary material). In the event of embedment technique of modification for electrodes coated with a mixed layer the peak current of reduction/oxidation process of $\left[\mathrm{Ru}\left(\mathrm{NH}_{3}\right)_{6}\right]^{3+}$ was much lower in comparison with thiol monolayer (Fig. 1A supplementary material). Access of $\left[\mathrm{Ru}\left(\mathrm{NH}_{3}\right)_{6}\right]^{3+}$ to the surface of electrodes modified by embedment was more hindered probably because of the bilayer structure of this SAM. 
Covalent modification led to monolayer creation. In this case for electrodes coated with a mixed layer was observed higher peak current in comparison with electrodes modified with thiol monolayer (Fig. 1B supplementary material). The created mixed layer was less ordered than that formed only by one type of thiol molecules and access of redox marker ions was facilitated.

Comparison of both investigated mixed SAMs showed that for electrodes coated with embedment lower peak current was observed. Access of redox marker molecules to the bilayer-modified electrode surface were more hindered than to the surface of electrodes modified covalently with mixed monolayer.

Similar results were obtained for electrodes modified with macrocyclic polyamine - also by covalent and embedment methods [30, 31], where the same correlation appeared.

For investigated SAMs EIS experiment was also performed. The results were displayed as the relation of the imaginary (-Z") versus the real (Z) impedance components plotted for various frequencies (the Nyquist plots

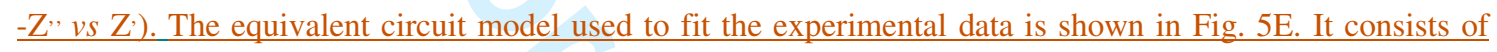
resistance solution Rs, constant phase element $\mathrm{Q}_{\mathrm{dl}}$, charge transfer resistance $\mathrm{R}_{\mathrm{ct}}$ and Wartburg element $\mathrm{Z}_{\mathrm{W}}$. The constant phase element (CPE, $\mathrm{Q}_{\mathrm{dI}}$ ) was used instead of the ideal capacitor in order to improve the fitting and minimize errors (typical plot of fitting is shown in Fig. 7 in the supplementary material). The CPE expressed the double-layer capacitance and its use is caused by a microscopic roughness or heterogenity of gold electrode surface [33].

The impedance of CPE is given by:

$\underline{\mathrm{Z}}_{\mathrm{CPE}}=1 /\left(\mathrm{Y}_{0} \mathrm{j} \omega\right)^{\mathrm{n}}$

where $\mathrm{Y}_{0}$ is CPE constant, $\mathrm{j}=(-1)^{1 / 2}, \omega=2 \pi f$ being $f$ the frequency of the applied ac potential and $\mathrm{n}$ is a fractional parameter equal from 0.5 (for an ideally porous electrode) to 1.0 (for a perfectly smooth electrode).

When $\mathrm{n}=1, \mathrm{Y}_{0} \equiv C_{\mathrm{dl}}$ (capacity of double layer) and purely capacitive behavior is obtained. A small deviation from $1.0(\mathrm{n}>0.9)$ was observed in this study, which suggests that $\mathrm{Y}_{0}$ parameter can be treated as a capacity of double layer.

Table 1 supplementary material showed values of $\mathrm{Y}_{0}$ constant for investigated SAMs. The value of this parameter decreases with increases in the thickness of the SAM. The value of $\mathrm{Y}_{0}$ for DDT monolayer prepared from $1.0 \mathrm{mM}$ solution was similar to that obtained for covalent modification. It can be explained by the fact that receptor 1 used for this modification had a side chain with similar length (C11) to the length of dodecanethiol chain $(\mathrm{C} 12)$ and these two monolayers could have comparable thickness. The value of $\mathrm{Y}_{0}$ for 
DDT monolayer prepared from $0.01 \mathrm{mM}$ solution was higher to those obtained for embedment modifications. It showed that embedment modification leads to the formation of ticker SAM in comparison with DDT layer. These results are in good agreement with results obtained for OSWV (Fig. 1 supplementary material).

\section{Sensitivity of tetralactam SAMs toward acrylic acid}

The determination of acrylic acid by gold electrodes modified with tetralactam by covalent and

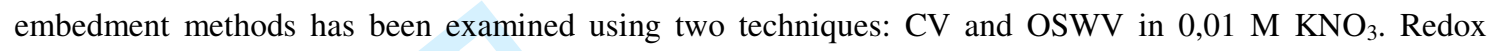
marker $\left[\mathrm{Ru}\left(\mathrm{NH}_{3}\right)_{6}\right] \mathrm{Cl}_{3}$ was most suitable for the investigated system. The negatively charged $\left[\mathrm{Fe}(\mathrm{CN})_{6}\right]^{3+/ 4+}$ was shown to be irreversible in cases of investigated modifications. Moreover, this marker demands higher concentration of supporting electrolyte $(0.1 \mathrm{M})$, which can decrease interaction between the host and anionic guest. Rutenium complex can be used in lower concentrations of supporting electrolyte $(0.01 \mathrm{M})$. Due to the reasons noted above, $\left[\mathrm{Ru}\left(\mathrm{NH}_{3}\right)_{6}\right]^{3+}$ was chosen.

The interaction between a tetralactam host immobilized on Au electrodes surface by covalent and embedment methods and anion of acrylic acid were investigated by voltammetric techniques CV and OSWV [34-37]. The measurements were performed in a $\mathrm{pH}=5.0$ solution. Electrodes modified with covalent technique showed different peak current (from -0.39 to $-1.07 \mu \mathrm{A}$ ) and peak potential (from -184.0 to -343.0 $\underline{\mathrm{mV})}$ in $0.01 \mathrm{M} \mathrm{KNO}_{3}$ solution containing $0.1 \mathrm{mM}\left[\mathrm{Ru}\left(\mathrm{NH}_{3} 2_{6}\right] \mathrm{Cl}_{3}\right.$. Electrodes modified with embedment method also showed differentiation in peak maximum parameters obtained in $0.01 \mathrm{M} \mathrm{KNO}_{3}$ solution containing $0.1 \mathrm{mM}\left[\mathrm{Ru}\left(\mathrm{NH}_{3}{ }_{2}{ }_{6}\right] \mathrm{Cl}_{3}\right.$. For modification with receptor 2, peak current values were in range from

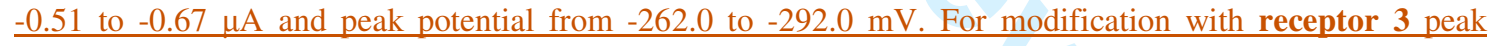
current was in range from -1.03 to $-1.68 \mu \mathrm{A}$ and peak potential -143.0 to $-163.0 \mathrm{mV}$. Because of this parameter of relative decreasing of peak current was used to evaluate their response. The ratio of OSWV peak current in the presence of different concentrations of acrylic acid $\left(\mathrm{I}_{\mathrm{p}}\right)$ to that in the absence of acrylic acid $\left(\mathrm{I}_{\mathrm{p}, 0)}\right.$

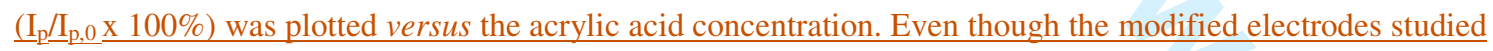
showed different maximum current in $0.01 \mathrm{M} \mathrm{KNO}_{3}$ solutions, all of them modified with the same method displayed similar sensitivity toward acrylic acid estimated with using the relative current decreasing $\left(I_{D} / \underline{I}_{0,0} \underline{x}\right.$ $\underline{100 \%)}$.

Electrodes modified by covalent method had similar detection limit, which was $1.0 \times 10^{-5} \mathrm{M}$, but $\underline{\text { slightly different linearity region in comparison with embedment modification with receptor } 2 \text {. In the case of }}$ 
covalent modification it was from $1.0 \times 10^{-5}$ to $2.5 \times 10^{-4}$, with slope $-42.8 \% /$ decade (obtained from the plot $\left.\underline{I}_{p} / \underline{I}_{p, 0} \times 100 \% v s \log \mathrm{c}\right)$ and regression coefficient 0.976 . In the case of embedment it was from $1.0 \times 10^{-5}$ to $1.0 \times 10^{-3} \mathrm{M}$ with slope $-10.6 \% /$ decade and regression coefficient 0.930 .

A stronger response toward acrylic acid was observe with electrodes modified by covalent method (Fig. 3, Fig. 2 supplementary material) in relation to those modified with embedment (Fig. 4). The highest acrylic acid concentration studied $\left(1.0 \times 10^{-3} \mathrm{M}\right)$ caused $67.5 \%$ current decrease in OSWV in the case of covalent modification and $21.3 \%$ for electrodes modified by embedment. Electrodes modified with acyclic derivative (receptor 3 ) were also investigated. These electrodes prepared by embedment and measured in the same conditions of $\mathrm{pH}$ showed inconsiderable response toward acrylic acid (Fig. 6 supplementary material). The cyclic voltammetry showed lower sensitivity as compared with square wave voltammetry. Important advantage of OSWV is the ability to suppress the background and because of that is more sensitive and more suitable for quantitative measurements. The results obtained by CV and OSWV are presented in the Fig. 3 and Fig. 2 supplementary material.

Electrochemical impedance spectroscopy (EIS) was used to detect acrylic acid with electrodes modified by covalent method. Results obtained with EIS were with good agreement with results obtained with OSWV. The observed range of response was similar in both cases. Results obtained with EIS are presented in Fig. 5. The equivalent circuit model used to fit the experimental data is shown in Fig. 5E. It consists of resistance solution $\mathrm{R}_{\underline{\underline{S}}}$, constant phase element $\mathrm{Q}_{\underline{\mathrm{d}}}$, charge transfer resistance $\mathrm{R}_{\underline{\underline{c t}} \underline{\mathrm{c}}}$ and Wartburg element $\mathrm{Z}_{\underline{\mathrm{w}}}$. Parameters such as solution resistance and the constant phase element should remain almost constant for measurements performed in the absence and in the presence of a faradaic process. Determination of these parameters in the absence of a reaction and using them as initial estimates in the presence of the reaction helps to reduce the error in the fit. However, faradaic impedance spectroscopy technique using a redox probe molecule and measured at the formal potential of the redox probe can reveal a dependence of electron transfer resistance in the SAM during complex formation. Formal potential of the redox marker was chosen as a potential at which the data were collected on the basis of references [38-40].

As a control experiment electrodes modified only with 1-dodecanethiol were used (Fig. 4 supplementary material). These electrodes showed only negligible response toward the analyte in the solution $\mathrm{pH}=5.0$. This proved that only the tetralactam host presence was responsible for recognition process.

Electrodes modified with acyclic derivative (receptor 3) also were investigated. These electrodes, prepared by embedment technique and measured in the same conditions of $\mathrm{pH}$, showed inconsiderable response toward
Deleted: The complex impedance was
displayed as the sum of the real $\left(\mathrm{Z}_{\mathrm{re}}\right)$ and
imaginary $\left(\mathrm{Z}_{\mathrm{im}}\right)$ components and
presented as Nyquist plots $\left(\mathrm{Z}_{\mathrm{im}} v s \quad \mathrm{Z}_{\mathrm{re}}\right)$. 
acrylic acid (Fig. 6 supplementary material). This suggested that only interaction between macrocyclic tetralactam and acrylic acid is sufficient.

\section{Mechanism of response}

In the present paper the interaction between acrylic acid and tetralactam molecules immobilized on the surface of gold electrodes either by the covalent or embedment methods was investigated. CV, OSWV and electrochemical impedance spectroscopy measurements were performed in the presence of $0.01 \mathrm{M} \mathrm{KNO}_{3}$ used as supporting electrolyte. Appropriate $\mathrm{pH}$ values (3.0, 5.0 and 6.2) were obtained by the addition of $\mathrm{KOH}$ or $\mathrm{HNO}_{3}$ solutions. Because of interference and suppressing of response no buffer solution was used.

At $\mathrm{pH}=5.0$ analyte existed in the solution in $85 \%$ as anionic form and in $15 \%$ as neutral form, whereas tetralactam existed in the layer on the electrode surface as a neutral compound. This ionophore and analyte in ionic or neutral form can interact by hydrogen bonds formation. Tetralactam macrocycle have four amide fragments, that can form strong H-bonds and can serve both as donors and acceptors of such bonds. $\pi-\pi$ interactions between double bonds of analyte and aromatic rings of host molecule also can play some role [16].

Geometry optimization of a number of different conformations of the macrocycle in vacuum using CaChe Workspace programme (CaChe Workststem Pro Version 7.5.0.85) and AM1 geometry procedure (MOPAC 2002 Version 2.5.3, J. J. P. Stewart, Fujitsu Limited, Tokyo, Japan) showed that most favorable conformation of the host molecule is when all four amide - $\mathrm{NH}$ group (acceptors of H-bond) are oriented inside the macrocycle cavity $(-185.10 \mathrm{~kJ})$. Conformation with one $-\mathrm{NH}$ group oriented outside the cavity is slightly less favorable $(-172.77 \mathrm{~kJ})$. These results are in good agreement with similar calculations in $\mathrm{CHCl}_{3}$ conducted by Kleefisch and coworkers [16] and structures obtained by X-ray crystallography [41]. These results indicate the strong $\mathrm{H}$-bond accepting character of the investigated macrocycle cavity.

Acrylic acid in dissociated form possess stronger electron donor characters and, because of that, stronger affinity to the tetralactam cavity in comparison with neutral form. That suggests that observed response was caused more by anionic than by neutral form of analyte.

In order to support the above conclusion OSWV and EIS experiments in solution $\mathrm{pH}=6.2$ was conducted. In these conditions about $100 \%$ of analyte existed in anionic form and the expected response of the sensor should be improved. However, electrodes measured in solution at higher $\mathrm{pH}$ showed considerably 
lower response for acrylate anion (Fig. 5, Fig. 5 supplementary material). A possible explanation for this phenomenon can be the interaction of the ionophore with $\mathrm{OH}^{-}$ions, which can also be strong H-bond donors and have high affinity to the tetralactam cavity.

Measurement conducted by EIS in $\mathrm{pH}=3.0$ (when analyte exist in solution in neutral form) showed no response of electrodes modified with covalent method towards acrylic acid. These results showed that $\mathrm{pH}=5.0$ was optimal for detection of the analyte and confirmed the conclusion that observed interaction occurs between the ionophore and anionic forms of analyte.

The working principal of the sensor presented suggests that it can be assigned to "ion-channel" or "ion-channel-mimetic" sensors. Umezawa and co-workers who have introduced these types of sensors have distinguished two types of such sensors according to mechanism of response: intermolecular and intramolecular ion-channel sensors [42-44]. In the first group electrostatic ion-ion interaction (electrostatic attraction or repulsion) and physical blocking of the intermolecular voids prevents access of redox marker to the electrode surface. Binding ionic analytes to the synthetic receptor layer changes the total charge of the layer and its permeability for marker ions. In intramolecular ion-channel sensors, access of markers to electrode surface through the intramolecular cavity of receptors can be blocked by the formation of inclusiontype complexes with an analyte.

In measuring conditions the acrylate anion can interact with neutral tetralactam molecules to form a negatively charged complex. This may give negative charge to the layer and increase attraction between the electrode and positively charged redox marker $\left[\mathrm{Ru}\left(\mathrm{NH}_{3}\right)_{6}\right]^{3+}$. However, a sensor reported decreasing of peak current. Probably the physical blocking of intermolecular spaces prevented access of marker ions to the electrode and played a decisive role in the generation of the investigated sensor response. This can be explained by the idea of an intermolecular ion-channel mechanism [42-44].

Supramolecular complex formations not only block reaction of electron transfer between the electrode and marker molecules but also affect its kinetics. Reversibility of the reduction/oxidation process of $\left[\mathrm{Ru}\left(\mathrm{NH}_{3}\right)_{6}\right]^{3+}$ decreased. So the maximum of peak current observed by OSWVs decreased and shifted to more negative potential values. In the case of covalent modification investigated in this work the highest acrylic acid concentration studied $\left(1.0 \times 10^{-3} \mathrm{M}\right)$ caused $67.5 \%$ current decrease in OSWV and a slight shift of peak potential. In the case of electrodes modified by embedment method lower current decrease $(21.3 \%)$, but higher negative shift of peak potential was observed. This phenomenon can be connected with different characters of two investigated monolayers. The embedment technique provide more flexibility of ionophore molecules in comparison with the covalent method, which can entail different characteristics of a complex 
formation. Upon increasing acrylate anion concentration the Faradaic current of redox reaction decreased for electrodes modified either by the covalent or embedment methods. The size of tetralactam cavity estimated by AM1 MOZYME geometry optimization (5.845 $\AA$ - the smallest width) but also estimated from CoreyPauling-Koltun atomic (CPK) model $(6.4 \AA)$ is large enough to hold the analyte (5.1 $\mathrm{\AA}$ - CPK model) but not large enough for the marker $\left[\mathrm{Ru}\left(\mathrm{NH}_{3}\right)_{6}\right]^{3+}(6.4 \AA$ [45]) to penetrate through. This also confirms the conclusion of investigated sensor work according to the intermolecular ion-channel sensor mechanism.

Gold electrodes coated with host molecule by covalent method showed higher sensitivity than those coated by embedment modification (Figs. 3, 4). Embedment technique provided higher flexibility of prepared layer. Macrocycle interacts with thiol layer via non-covalent interaction and has the possibility to take the most suitable conformation for interaction with analyte. The covalent technique did not provide such "conformational freedom". Because of the above reasons, higher sensitivity for embedment modification was expected. However, obtained results were different.

Measured tetralactam is 32-membered macrocycle which possess six benzene ring fragments and, as the CPK model showed, is rather rigid and does not have the ability to adopt its conformation. Another possible explanation can be the difference in structure of two investigated layers. The covalent technique makes it possible to create a monolayer containing tetralactam molecules. In the case of embedment technique a bilayer is formed and ionophore molecules recede from the electrode surface, which can explain the decrease of sensitivity.

In this case a crucial factor can also be the density of electrode surface coverage by the host molecules, which for the covalent method can be higher. Investigated tetralactam after modification is covalently bonded to the electrode surface via one side chain. Embedment assumes the attachment of the macrocycle by hydrophobic and van der Waals interactions between the alkanethiol monolayer and aliphatic side chain of host molecule. Measured tetralactam possess only one side chain and because of that such prepared SAMs were less stable and less reproducible in comparison with the covalent method.

A similar comparison of these two techniques of immobilization was made using polyamine macrocycle [30, 31]. This 30-membered macrocycle possess two aromatic rings as fragments of macrocycle. Electrodes modified with this bigger and significantly more flexible molecule by embedment showed better sensitivity than those coated by covalent technique. Moreover, these macrocycles formed stable and reproducible SAMs via six aliphatic side chains versus the investigated tetralactam that possessed one side chain. 


\section{Conclusions}

It was proved that tetralactam macrocycle can be used as the host molecule of chemically modified gold electrodes destined for detection of acrylic acid in water solution.

The interaction between the tetralactam host and acrylate guest could be observed using Osteryoung square wave voltammetry (OSWV) and electrochemical impedance spectroscopy (EIS).

The covalent method of host immobilization on the gold electrode surface was more suitable than embedment. Electrodes modified by covalent technique were characterized by better sensor-to-sensor repeatability in comparison to those modified by embedment.

Faradaic impedance spectroscopy as well as CV and OSWV was used to investigate reported systems and based on results obtained with these methods intermolecular ion channel mechanism of response was proposed.

\section{Acknowledgements}

This work was supported by European grant COST D31/0021/05 and grants from the Polish Ministry of Science and Higher Education No. 19/COS/2006/3, No. 2PO6T08827 and Institute of Animal Reproduction and Food Research of Polish Academy of Sciences.

\section{References}

[1] Ruden, C. Food Chem. Toxicol. 2004, 42, 335.

[2] Friedman, M. J. Agric. Food Chem. 2003, 51, 4504.

[3] Tareke, E.; Rydberg, P.; Karlsson, P.; Eriksson, S.; Törnqvist, M. J. Agric. Food Chem. 2002, 50, 4998.

[4] Gökmen, V.; Senyuva, H. Z.; Acar, J.; Sarioglu, K. J. Chromatogr., A, 2005, 1088, 193.

[5] Becalski, A.; Lau, B. P.-Y.; Lewis, D.; Seaman, S. W. J. Agric. Food Chem. 2003, 51, 802.

[6] Mottram, D. S.; Wedzicha, B. L.; Dodson, A. T. Nature 2002, 419, 448.

[7] Stadler, R. H.; Blank, I.; Varga, N.; Robert, F.; Hau, J.; Guy, P. A.; Robert, M.-C.; Riediker, S. Nature 2002, 419, 449.

[8] Zyzak, D.V.; Sanders, R. A.; Stojanovic, M.; Tallmadge, D. H.; Eberhart, B. L.; Ewald, D. K.; Gruber, D. C.; Morsch, T. R.; Strothers, M. A.; Rizzi, G. P.; Villagran, M. D. J. Agric. Food Chem. 2003, $51,4782$. 
1

[9] Mizukami, Y.; Kohata, K.; Yamaguchi, Y.; Hayashi, N.; Sawai, Y.; Chuda, Y.; Ono, H.; Yada, H.;

Yoshida, M. J. Agric. Food Chem. 2006, 54, 7370.

[10] Hoenicke, K.; Gatermann, R.; Harder, W.; Hartig, L. Anal. Chim. Acta 2004, 520, 207.

[11] Robert, F.; Vuataz, G.; Pollien, P.; Saucy, F.; Alonso, M.-I.; Bauwens, I.; Blank, I. J. Agric. Food Chem. 2005, 53, 4628 .

[12] Stobiecka, A.; Radecka, H.; Radecki, J. Biosens. Bioelectron. 2007, 22, 2165.

[13] Steward, J. M.; Bhattacharaya, S. K.; Madura, R. L., Mason, S. H.; Schonberg, J. C. Water Res. 1995, 29 , 2730.

[14] Casella, I. G.; Pierri, M.; Contursi, M. J. Chromatogr., A 2006, 1107, 198.

[15] Ignatov, O. V.; Rogatcheva, S. M.; Kozulin S. V.; Khorkina N. A. Biosens. Bioelectron. 1996, $12,105$.

[16] Kleefish, G.; Kreutz Ch.; Bargon, J.; Silva, G.; Schalley, Ch. A. Sensors 2004, 4,136.

[17] Choi, K.; Hamilton, A. D. Coord. Chem. Rev. 2003, 240, 101.

[18] Sigel, H.; Martin, R. B. Chem Rev. 1982, 82, 385.

[19] Hunter, Ch. A. J. Chem. Soc. Chem. Commun. 1991, 749.

[20] Hubner, G. M.; Glaser, J.; Seel, Ch.; Vogtle, F. Angew. Chem., Int. Ed. 1999, 38, 383.

[21] Bargon, J.; Braschoß, S.; Florke, J.; Herrmann, U.; Klein, L.; Loergen, J. W.; Lopez, M.; Maric, S.; Parham, A. H.; Piacenza, P.; Schaefgen, H.; Schalley, C. A.; Silva, G.; Schlupp, M.; Schwierz, H.; Vogtle, F.; Windscheif, G. Sens. Actuators, B 2003, 95, 6.

[22] Herrmann, U.; Jonischkeit, T.; Bargon, J.; Hahn, U.; Li, Q.-Y.; Schalley, Ch.A.; Vogel, E.; Vogtle, F. Anal. Bioanal. Chem. 2002, 372, 611.

[23] Hunter, Ch. A. J. Am. Chem. Soc. 1992, 114, 5303.

[24] Vogtle, F.; Jager, R.; Handel, M.; Ottens-Hildebrandt, S. Pure Appl. Chem. 1996, 68, 225.

[25] Vogtle, F.; Handel, M.; Meier, S.; Ottens-Hildebrandt, S.; Ott, F.; Schmidt, T. Liebigs Ann. $1995,739$.

[26] Chang, S.-Y.; Kim, H.S.; Chang, K.-J.; Jeong, K.-S. Org. Lett. 2004, 6, 181.

[27] Kimura, K.; Meurer, D.L.; Hutzler, R. F.; Fitch, J. W.; Cassidy, P. E.. Macromolecules 1994, $27,1303$.

[28] Okubo, H.; Yamaguchi, M. J. Org. Chem. 2001, 66, 824.

[29] Muscat, D.; Witte, A.; Köhler, W.; Müllen, K.; Geerts, Y. Macromol. Rapid. Commun. 1997, 18, 233.

[30] Radecki, J.; Szymańska, I.; Bulgariu, L.; Pietraszkiewicz, M. Electrochim. Acta, 2006, 51, 2289.

[31] Radecka, H.; Szymańska, I.; Pietraszkiewicz, M.; Pietraszkiewicz, O.; Aoki, H.; Umezawa, Y. Chem. Anal. (Warsaw) 2005, 50, 85.

[32] Riepl, M.; Mirsky, V. M.; Wolfbeis, O. S. Mikrochim. Acta 1999, 131, 29. 
[33] Lasia, A. in Conway, B. E.; Bockris, J.; White, R.E. (Edts.), Electrochemical Impedance Spectroscopy and Its Applications, Modern Aspects of Electrochemistry. Kluwer Academic/PlenumPublishers, New York, 1999

[34] Bard, A. J.; Faulkner, L. R. Electrochemical methods. Fundamentals and applications. John Wiley and sons, Inc., New York, 2001

[35] Christie, J. H.; Tuner, J. A.; Osteryoung, R. A. Anal. Chem. 1977, 49, 1899.

[36] Tuner, J. A.; Christie, J. H.; Vucovic, M.; Osteryoung, R. A. Anal.Chem. 1977, 49, 1904.

[37] Fatouros, N.; Krulic, D. J. Electroanal. Chem. 2002, 520, 1.

[38] Protsailo, L. V.; Fawcett, W. R. Electrochim. Acta 2000, 45, 3497.

[39] Bandyopadhyay, K.; Liu, S.G.; Liu, H.; Echegoyen, L. Chem.Eur. J. 2000, 6, 4385.

[40] Flink, S.; Boukamp, B.A.; von den Berg, A.; van Veggel, F.C.J.M.; Reinhoudt, D.N. J.Am.Chem.Soc. 1998, 120,4652 .

[41] Reuter, C; Seel, C.; Nieger, M.; Vogtle, F. Helv. Chim. Acta 2000, 83, 630.

[42] Sugawara, M.; Kojima, K.; Sazawa, H.; Umezava, Y. Anal. Chem. 1987, 59, 2842.

[43] Umezawa, Y.; Aoki, H. Anal. Chem. 2004, 76, 320A.

[44] Buhlmann, P.; Aoki, H.; Xiao, K. P.; Amemiya, S.; Tohda, K.; Umezawa, Y. Electroanalysis 1998, 10, 1149 .

[45] Chailapakul, O.; Crooks, R. M. Langmuir 1995, 11, 1329. 
Figure captions

Figure 1. Structural formulas of ionophores used for modification of electrodes with covalent (A) and embedment methods (B, C).

Figure 2. Synthetic route to obtain receptors 2 and 3 (A) and receptor 1 (B).

Figure 3. (A) The OSWV curves for $\left[\mathrm{Ru}\left(\mathrm{NH}_{3}\right)_{6}\right]^{3+}$ measured with electrodes modified by covalent method (receptor 1) in the presence of various concentrations of acrylic acid. The electrolyte composition: $0.01 \mathrm{M}$ $\mathrm{KNO}_{3}, \mathrm{pH}=5.0,0.1 \mathrm{mM}\left[\mathrm{Ru}\left(\mathrm{NH}_{3}\right)_{6}\right]^{3+}$. Step potential: $5 \mathrm{mV}$, square-wave frequency $100 \mathrm{~Hz}$, and squarewave amplitude $25 \mathrm{mV}$. The concentration of the analyte was: (A) 0 , (B) $1.0 \times 10^{-6}$, (C) $1.0 \times 10^{-5}$, (D) $2.5 \times$ $10^{-5}$, (E) $5.0 \times 10^{-5}$, (F) $1.0 \times 10^{-4}$, (G) $2.5 \times 10^{-4}$, (H) $5.0 \times 10^{-4}$, (I) $1.0 \times 10^{-3} \mathrm{M}$.

(B) The ratio of OSWV peak current in the presence of different concentrations of acrylic acid $\left(\mathrm{I}_{\mathrm{p}}\right)$ to that in the absence of acrylic acid $\left(\mathrm{I}_{\mathrm{p}, 0}\right)$ as a function of the acrylic acid concentration. The currents were measured at the peak potential in OSWV curves in the solution with no analyte $\mathrm{E}_{\mathrm{p}, 0}=-243 \mathrm{mV}, \mathrm{n}=3,5.4 \%<\mathrm{SD}<15.0 \%$.

Figure 4. The ratio of OSWV peak current with electrodes modified by embedment technique with receptor 2 in the presence of different concentrations of acrylic acid $\left(\mathrm{I}_{\mathrm{p}}\right)$ to that in the absence of acrylic acid $\left(\mathrm{I}_{\mathrm{p}, 0}\right)$ as a function of the acrylic acid concentration. The currents were measured at the peak potential in OSWV curves in the solution with no analyte $\mathrm{E}_{\mathrm{p}, 0}=-292 \mathrm{mV}, \mathrm{n}=3,3.6 \%<\mathrm{SD}<7.7 \%$.

Figure 5. Impedance plots of $0.1 \mathrm{mM}\left[\mathrm{Ru}\left(\mathrm{NH}_{3}\right)_{6}\right]^{3+}$ measured in the absence and in the presence of different concentrations of acrylic acid in the solution of $0.01 \mathrm{M} \mathrm{KNO}_{3}$ (A) $\mathrm{pH}=3.0$, (B) $\mathrm{pH}=5.0,(\mathrm{C}) \mathrm{pH}=6.2$; (D) Plot of relative change of $\mathrm{R}_{\mathrm{ct}}$ with concentration of analyte for solutions $\mathrm{pH}=3.0(\mathbf{\Delta}), 5.0(\mathbf{\bullet}), 6.2(\bullet)$, (E) Equivalent circuit used to fit the experimental data: $R_{S}$ represents the solution, $Q_{d l}-$ constant phase element, $\mathrm{R}_{\mathrm{ct}}-$ charge transfer resistance, $\mathrm{Z}_{\mathrm{W}}-$ Wartburg element.

Graphical abstract

Model of complex formation between tetralactam and acrylate (CaChe Workststem Pro Version 7.5.0.85, Fujitsu Limited, Tokyo, Japan). 


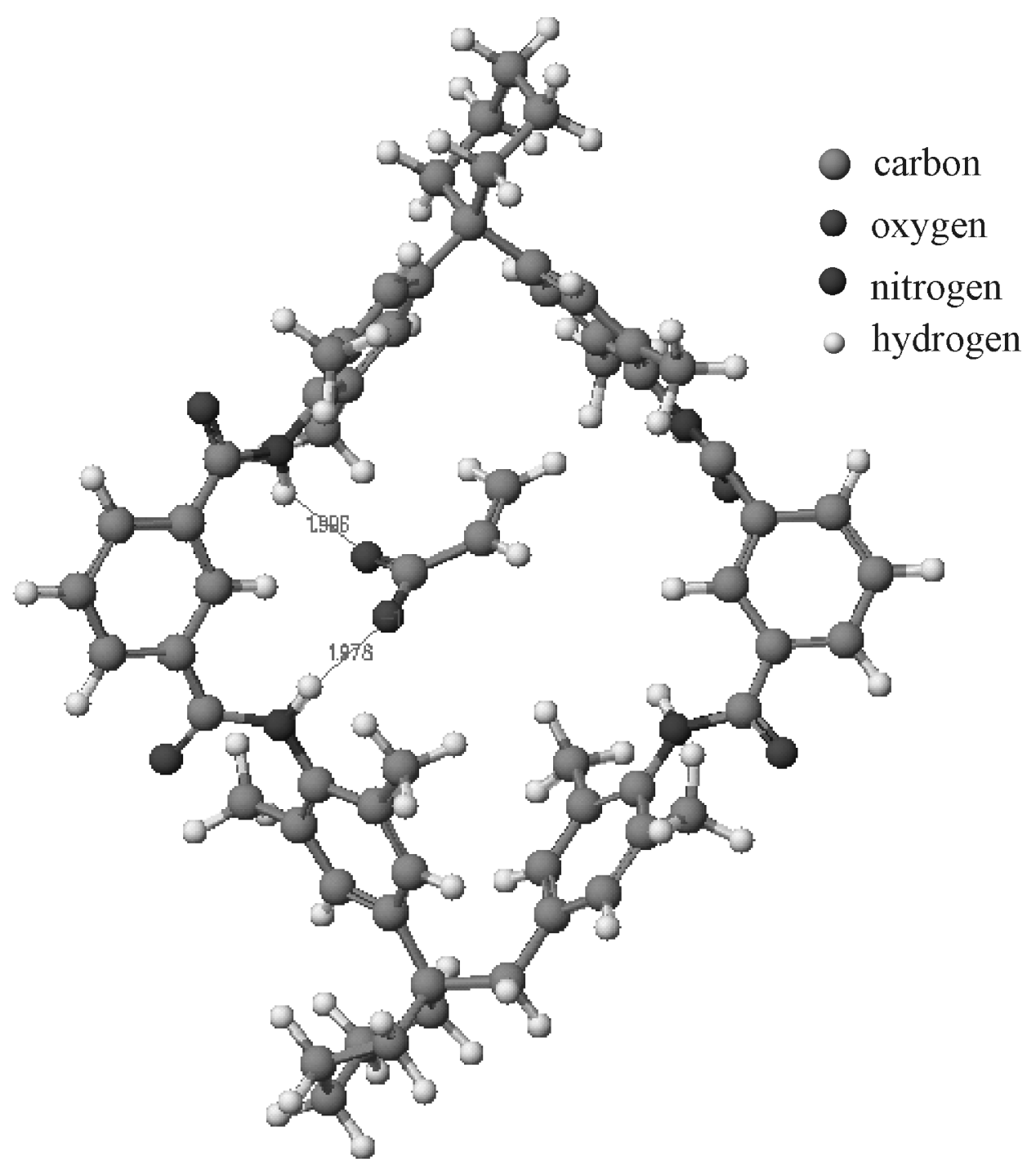

Model of complex formation between tetralactam and acrylate (CaChe Workststem Pro Version 7.5.0.85, Fujitsu Limited, Tokyo, Japan). 
1

2

3

4

5

6
7

8

9

10

11

12

13

14

15

16

17

18

19

20

21

22

23

24

25

26

27

28

29

30

31

32

33

34

35

36

37

38

39

40

41

42

43

44

45

46

47

48

49

50

51

52

53

54

55

56

57

58

59

60

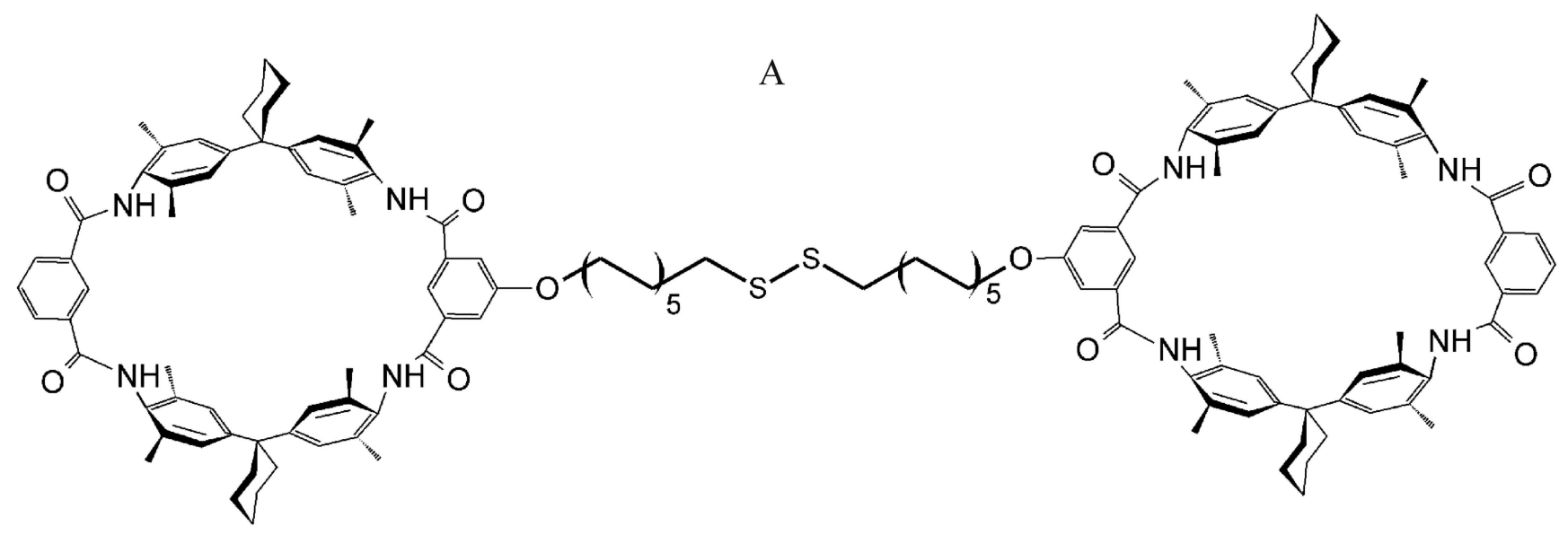

Figure 1. Structural formulas of ionophores used for modification of electrodes with covalent (A) and embedment methods $(B, C)$. 


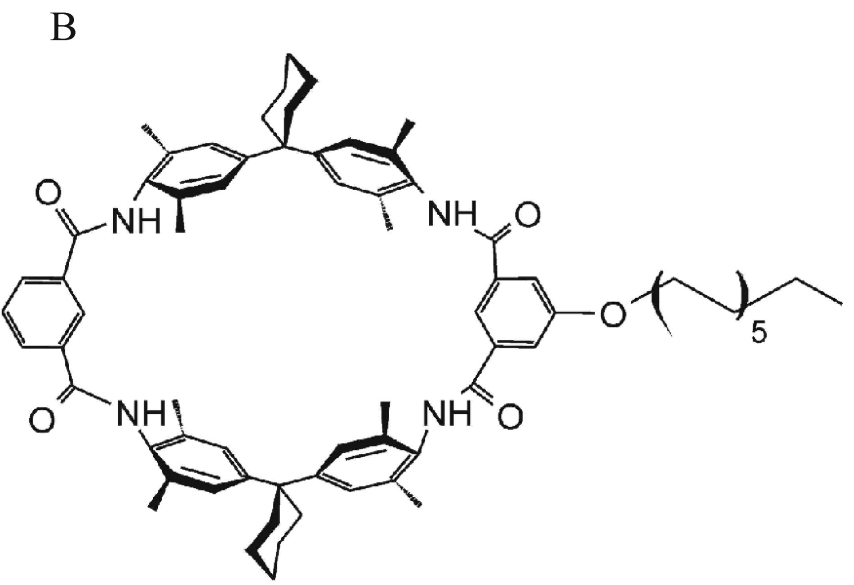

Figure 1. Structural formulas of ionophores used for modification of electrodes with covalent (A) and embedment methods (B, C). 
1

2

3

4

5

6

7

8

10

11

12

13
14

15

16

17

18

19

20

21

22

23

24

25

26

27

28

29

30

31

32

33

34

35

36

37

38

39

40

41

42

43

44

45

46

47

48

49

50

51

52

53

54

55

56

57

58

59

60

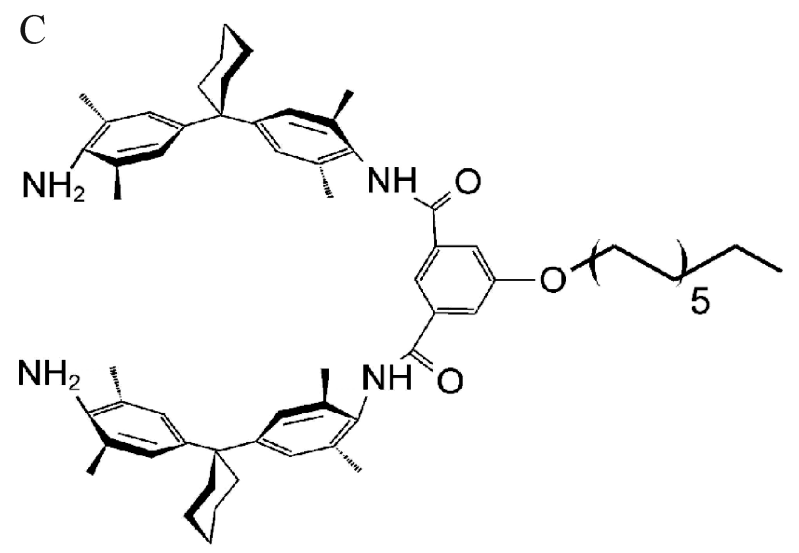

Figure 1. Structural formulas of ionophores used for modification of electrodes with covalent (A) and embedment methods $(\mathrm{B}, \mathrm{C})$. 


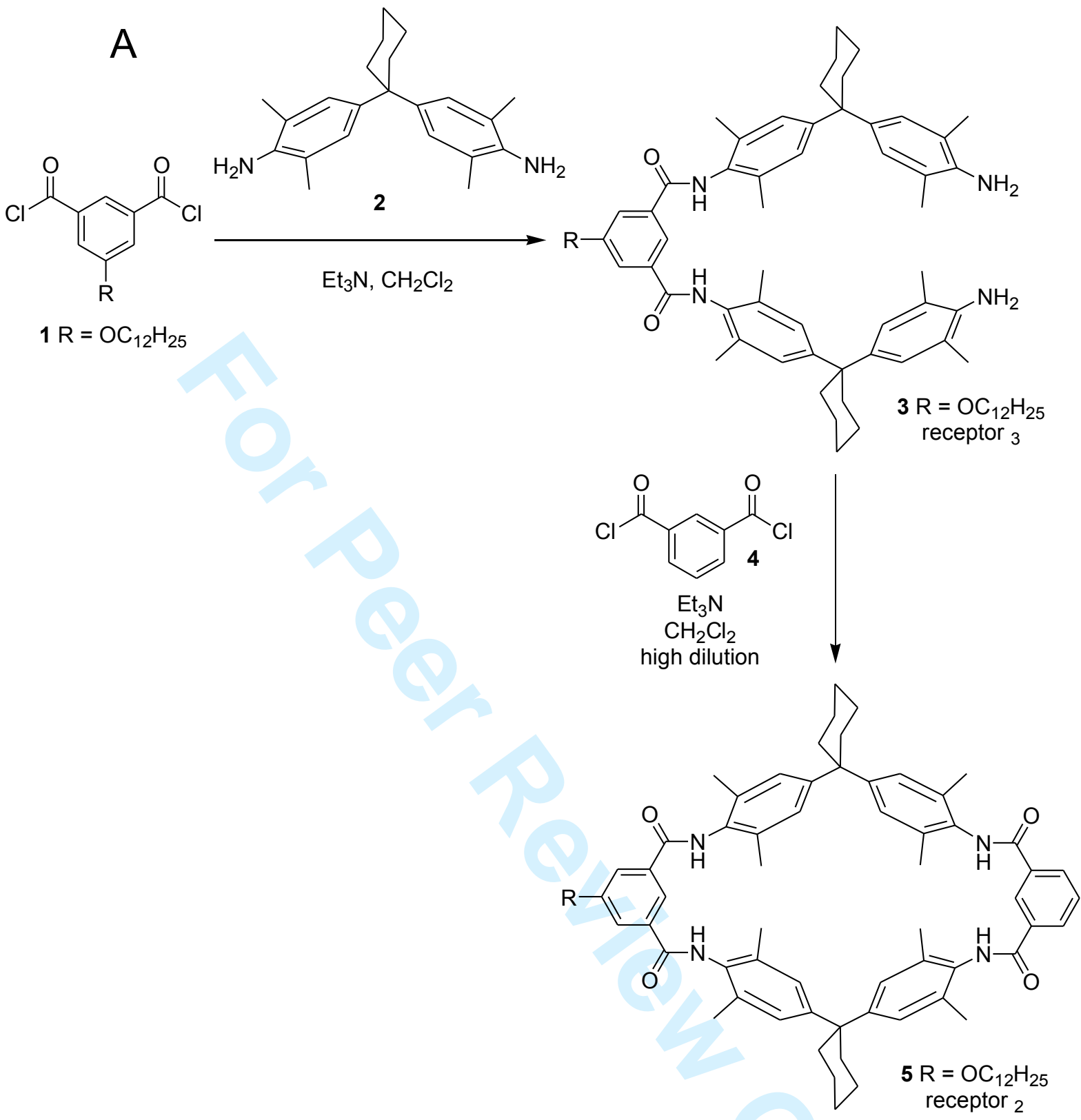

Figure 2. Synthetic route to obtain receptors 2 and 3 (A) and receptor 1 (B). 

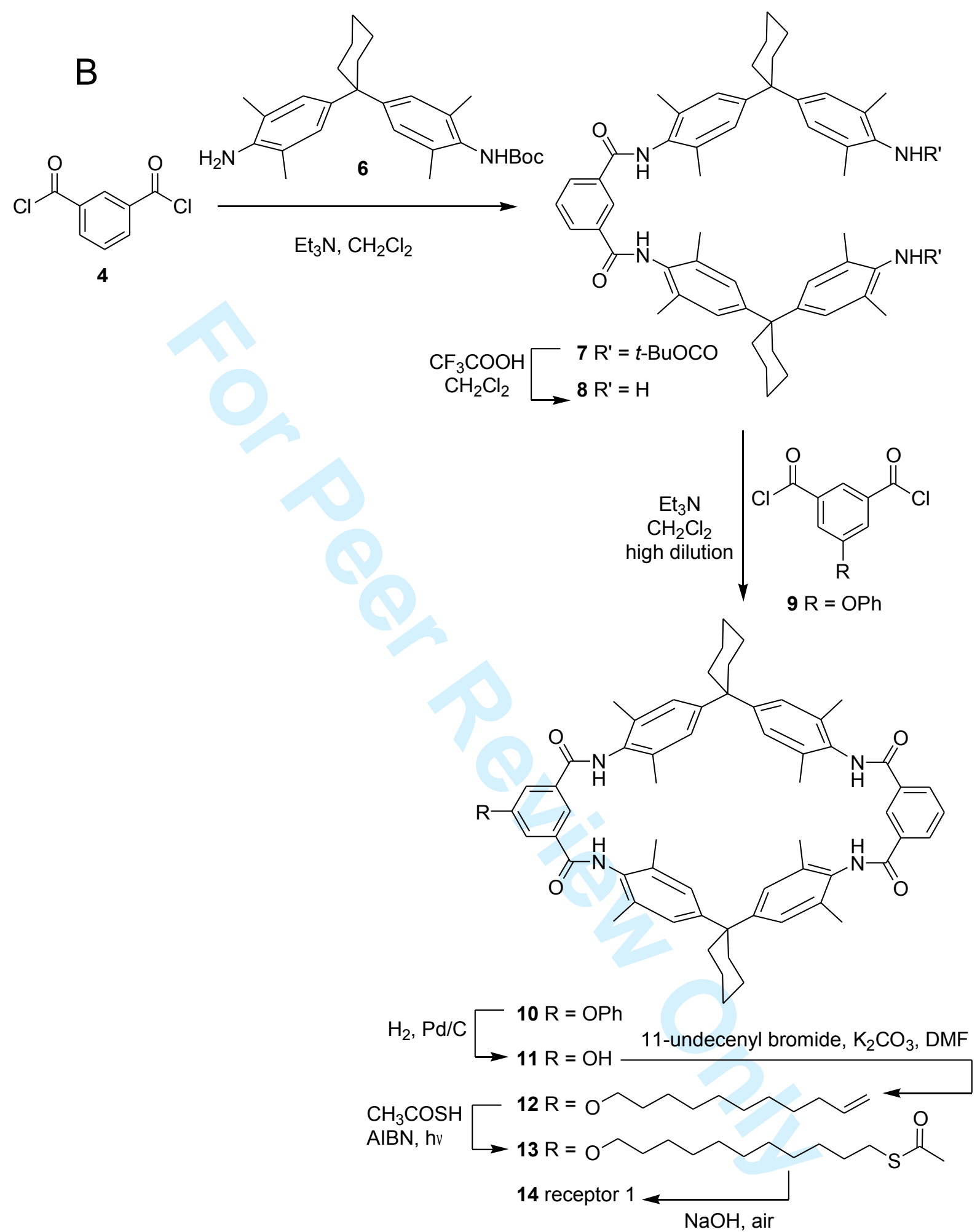

Figure 2. Synthetic route to obtain receptors 2 and 3 (A) and receptor 1 (B). 


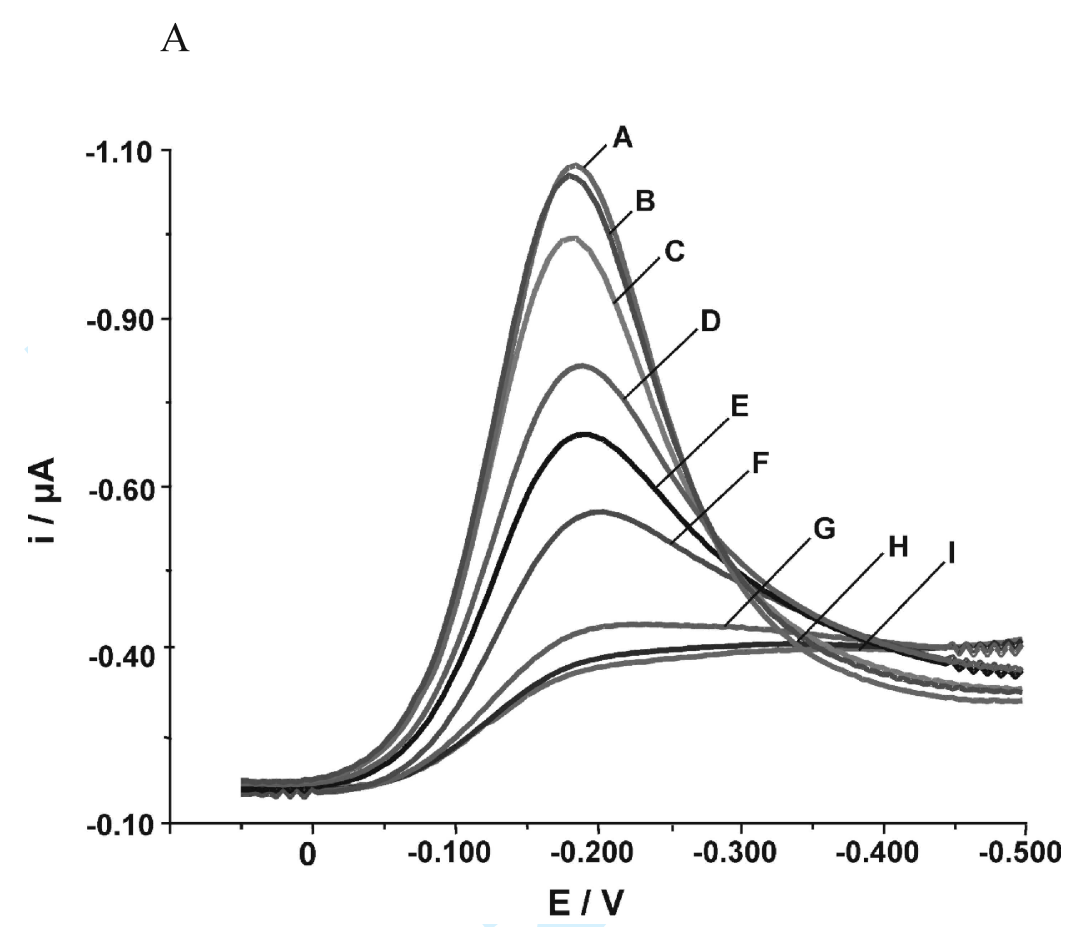

Figure 3. (A) The OSWV curves for $\left[\mathrm{Ru}\left(\mathrm{NH}_{3}\right)_{6}\right]^{3+}$ measured with electrodes modified by covalent method (receptor 1) in the presence of various concentrations of acrylic acid. The electrolyte composition: $0.01 \mathrm{M} \mathrm{KNO}_{3}, \mathrm{pH}=5.0,0.1 \mathrm{mM}\left[\mathrm{Ru}\left(\mathrm{NH}_{3}\right)_{6}\right]^{3+}$. Step potential: $5 \mathrm{mV}$, square-wave frequency $100 \mathrm{~Hz}$, and square-wave amplitude $25 \mathrm{mV}$. The concentration of the analyte was: (A) 0, (B) $1.0 \times 10^{-6}$, (C) $1.0 \times 10^{-5}$, (D) $2.5 \times 10^{-5}$, (E) $5.0 \times 10^{-5}$, (F) $1.0 \times 10^{-4}$, (G) $2.5 \times 10^{-4}$, (H) $5.0 \times 10^{-4}$, (I) $1.0 \times 10^{-3} \mathrm{M}$.

(B) The ratio of OSWV peak current in the presence of different concentrations of acrylic acid $\left(\mathrm{I}_{\mathrm{p}}\right)$ to that in the absence of acrylic acid $\left(\mathrm{I}_{\mathrm{p}, 0}\right)$ as a function of the acrylic acid concentration. The currents were measured at the peak potential in OSWV curves in the solution with no analyte $\mathrm{E}_{\mathrm{p}, 0}=-243 \mathrm{mV}$, $\mathrm{n}=3,5.4 \%<\mathrm{SD}<15.0 \%$. 
Figure 3. (A) The OSWV curves for $\left[\mathrm{Ru}\left(\mathrm{NH}_{3}\right)_{6}\right]^{3+}$ measured with electrodes modified by covalent method (receptor 1) in the presence of various concentrations of acrylic acid. The electrolyte

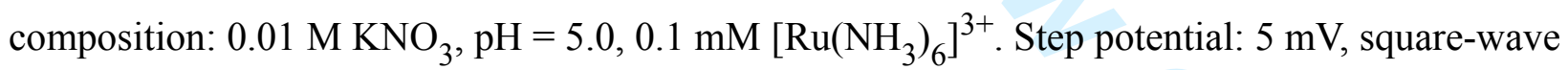
frequency $100 \mathrm{~Hz}$, and square-wave amplitude $25 \mathrm{mV}$. The concentration of the analyte was: (A) 0, (B) $1.0 \times 10^{-6}$, (C) $1.0 \times 10^{-5}$, (D) $2.5 \times 10^{-5}$, (E) $5.0 \times 10^{-5}$, (F) $1.0 \times 10^{-4}$, (G) $2.5 \times 10^{-4}$, (H) $5.0 \times 10^{-4}$, (I) $1.0 \times 10^{-3} \mathrm{M}$.

(B) The ratio of OSWV peak current in the presence of different concentrations of acrylic acid $\left(\mathrm{I}_{\mathrm{p}}\right)$ to that in the absence of acrylic acid $\left(\mathrm{I}_{\mathrm{p}, 0}\right)$ as a function of the acrylic acid concentration. The currents were measured at the peak potential in OSWV curves in the solution with no analyte $\mathrm{E}_{\mathrm{p}, 0}=-243 \mathrm{mV}$, $\mathrm{n}=3,5.4 \%<\mathrm{SD}<15.0 \%$. 
Figure 4. The ratio of OSWV peak current with electrodes modified by embedment technique with receptor 2 in the presence of different concentrations of acrylic acid $\left(I_{p}\right)$ to that in the absence of acrylic acid $\left(\mathrm{I}_{\mathrm{p}, 0}\right)$ as a function of the acrylic acid concentration. The currents were measured at the peak potential in OSWV curves in the solution with no analyte $\mathrm{E}_{\mathrm{p}, 0}=-292 \mathrm{mV}, \mathrm{n}=3,3.6 \%<\mathrm{SD}<7.7 \%$. 
Figure 5. Impedance plots of $0.1 \mathrm{mM}\left[\mathrm{Ru}\left(\mathrm{NH}_{3}\right)_{6}\right]^{3+}$ measured in the absence and in the presence of different concentrations of acrylic acid in the solution of $0.01 \mathrm{M} \mathrm{KNO}_{3}$ (A) $\mathrm{pH}=3.0$, (B) $\mathrm{pH}=5.0,(\mathrm{C})$ $\mathrm{pH}=6.2$; (D) Plot of relative change of $\mathrm{R}_{\mathrm{ct}}$ with concentration of analyte for solutions $\mathrm{pH}=3.0$ ( $\boldsymbol{\Delta}$ ), 5.0 $(\bullet), 6.2(\bullet)$, (E) Equivalent circuit used to fit the experimental data: $\mathrm{R}_{\mathrm{S}}$ represents the solution, $\mathrm{Q}_{\mathrm{dl}}-$ constant phase element, $\mathrm{R}_{\mathrm{ct}}-$ charge transfer resistance, $\mathrm{Z}_{\mathrm{W}}-$ Wartburg element. 
Figure 5. Impedance plots of $0.1 \mathrm{mM}\left[\mathrm{Ru}\left(\mathrm{NH}_{3}\right)_{6}\right]^{3+}$ measured in the absence and in the presence of different concentrations of acrylic acid in the solution of $0.01 \mathrm{M} \mathrm{KNO}_{3}$ (A) $\mathrm{pH}=3.0$, (B) $\mathrm{pH}=5.0$, (C) $\mathrm{pH}=6.2$; (D) Plot of relative change of $\mathrm{R}_{\mathrm{ct}}$ with concentration of analyte for solutions $\mathrm{pH}=3.0$ ( $\mathbf{\Lambda}$ ), 5.0 $(\bullet), 6.2(\bullet)$, (E) Equivalent circuit used to fit the experimental data: $\mathrm{R}_{\mathrm{S}}$ represents the solution, $\mathrm{Q}_{\mathrm{dl}}-$ constant phase element, $\mathrm{R}_{\mathrm{ct}}-$ charge transfer resistance, $\mathrm{Z}_{\mathrm{W}}-$ Wartburg element. 


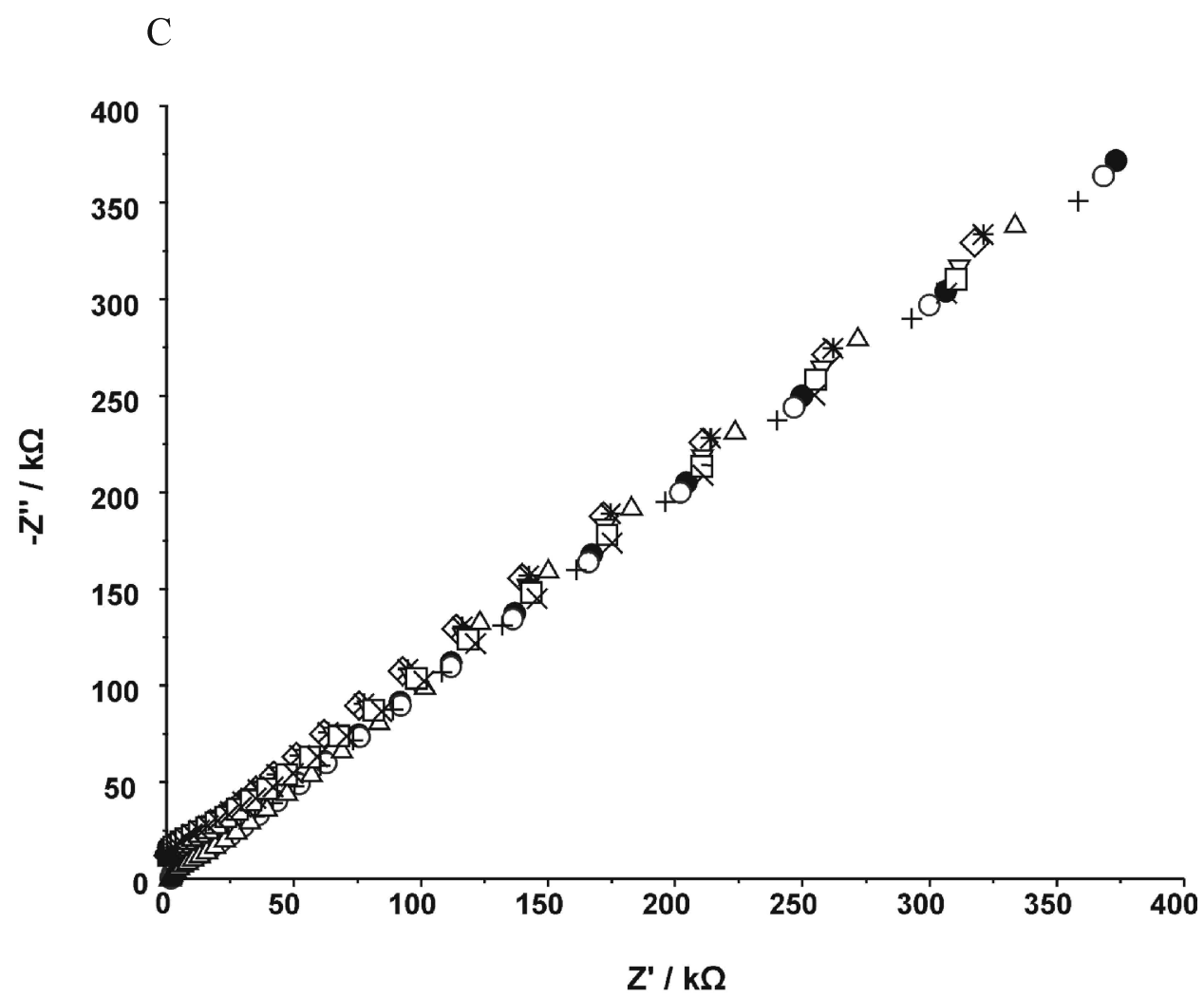

Figure 5. Impedance plots of $0.1 \mathrm{mM}\left[\mathrm{Ru}\left(\mathrm{NH}_{3}\right)_{6}\right]^{3+}$ measured in the absence and in the presence of different concentrations of acrylic acid in the solution of $0.01 \mathrm{M} \mathrm{KNO}_{3}$ (A) $\mathrm{pH}=3.0$, (B) $\mathrm{pH}=5.0$, (C) $\mathrm{pH}=6.2$; (D) Plot of relative change of $\mathrm{R}_{\mathrm{ct}}$ with concentration of analyte for solutions $\mathrm{pH}=3.0(\boldsymbol{\Delta}), 5.0$ $(\bullet), 6.2(\bullet)$, (E) Equivalent circuit used to fit the experimental data: $\mathrm{R}_{\mathrm{S}}$ represents the solution, $\mathrm{Q}_{\mathrm{dl}}-$ constant phase element, $\mathrm{R}_{\mathrm{ct}}-$ charge transfer resistance, $\mathrm{Z}_{\mathrm{W}}-$ Wartburg element. 


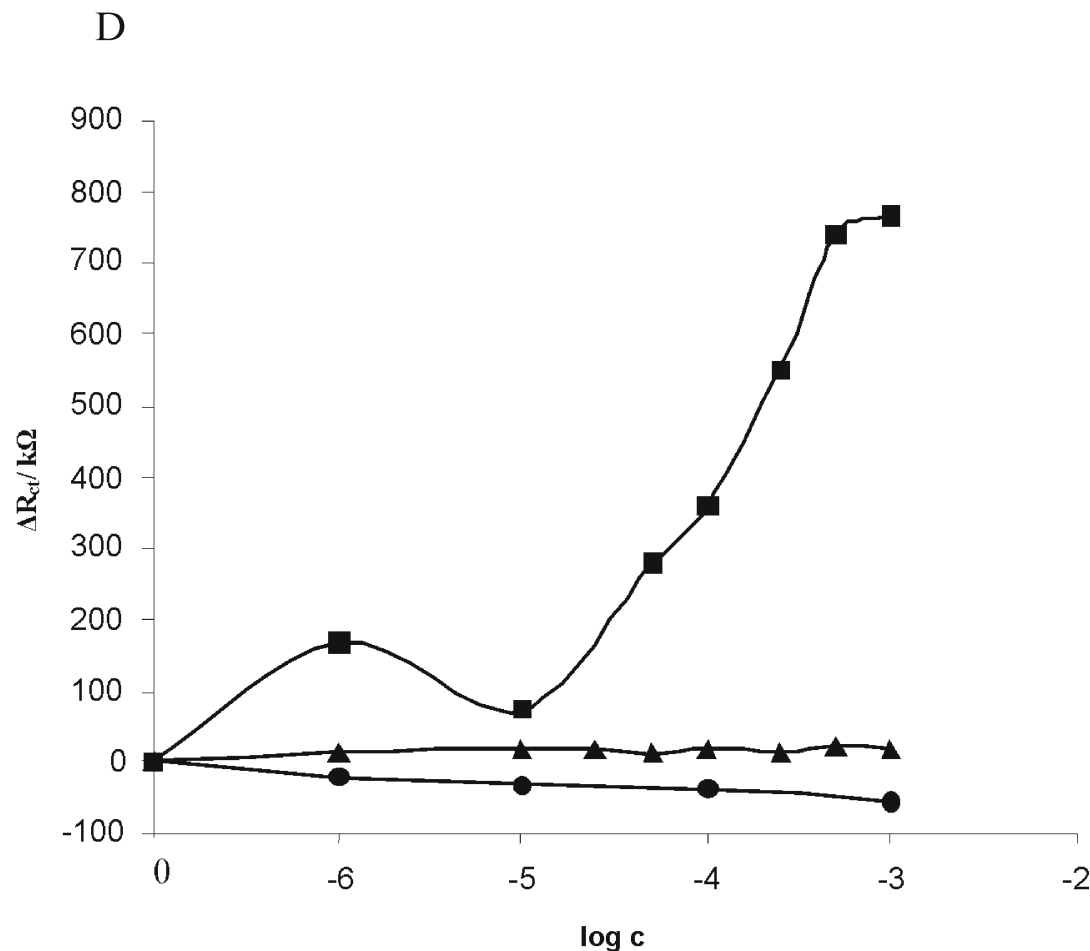

Figure 5. Impedance plots of $0.1 \mathrm{mM}\left[\mathrm{Ru}\left(\mathrm{NH}_{3}\right)_{6}\right]^{3+}$ measured in the absence and in the presence of different concentrations of acrylic acid in the solution of $0.01 \mathrm{M} \mathrm{KNO}_{3}(\mathrm{~A}) \mathrm{pH}=3.0,(\mathrm{~B}) \mathrm{pH}=5.0,(\mathrm{C})$ $\mathrm{pH}=6.2$; (D) Plot of relative change of $\mathrm{R}_{\mathrm{ct}}$ with concentration of analyte for solutions $\mathrm{pH}=3.0(\boldsymbol{\Delta}), 5.0$ $(\square), 6.2(\bullet)$, (E) Equivalent circuit used to fit the experimental data: $\mathrm{R}_{\mathrm{S}}$ represents the solution, $\mathrm{Q}_{\mathrm{dl}}-$ constant phase element, $\mathrm{R}_{\mathrm{ct}}$ - charge transfer resistance, $\mathrm{Z}_{\mathrm{W}}-$ Wartburg element. 
1

2

3

4

5

6

7

8

10

11

12

13

14

15

16

17

18

19

20

21

22

23

24

25

26

27

28

29

30

31

32

33

34

35

36

37

38

39

40

41

42

43

44

45

46

47

48

49

50

51

52

53

54

55

56

57

58

59

60

E

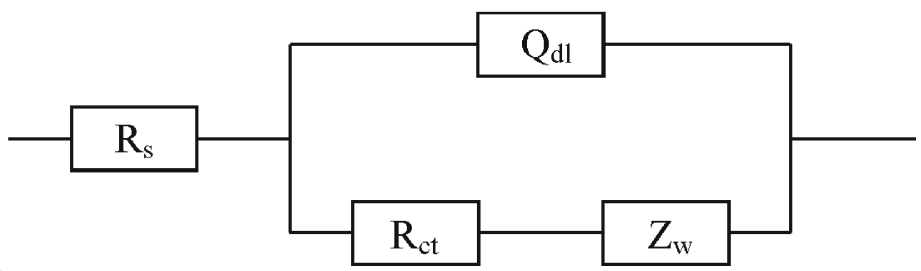

Figure 5. Impedance plots of $0.1 \mathrm{mM}\left[\mathrm{Ru}\left(\mathrm{NH}_{3}\right)_{6}\right]^{3+}$ measured in the absence and in the presence of different concentrations of acrylic acid in the solution of $0.01 \mathrm{M} \mathrm{KNO}_{3}(\mathrm{~A}) \mathrm{pH}=3.0,(\mathrm{~B}) \mathrm{pH}=5.0,(\mathrm{C})$ $\mathrm{pH}=6.2$; (D) Plot of relative change of $\mathrm{R}_{\mathrm{ct}}$ with concentration of analyte for solutions $\mathrm{pH}=3.0(\boldsymbol{\Delta}), 5.0$ $(\square), 6.2(\bullet)$, (E) Equivalent circuit used to fit the experimental data: $\mathrm{R}_{\mathrm{S}}$ represents the solution, $\mathrm{Q}_{\mathrm{dl}}-$ constant phase element, $\mathrm{R}_{\mathrm{ct}}-$ charge transfer resistance, $\mathrm{Z}_{\mathrm{W}}-$ Wartburg element. 


\title{
SUPPLEMENTARY MATERIAL
}

\section{Tetralactam-Modified Gold Electrodes for Amperometric Detection of Acrylic Acid}

\author{
A. Krajewska ${ }^{a}$, M. Smet ${ }^{b}$, W. Dehaen ${ }^{b}$, H. Radecka ${ }^{a}$ \\ ${ }^{a}$ Institute of Animal Reproduction and Food Research, Polish Academy of Sciences, \\ Tuwima 10, 10-747 Olsztyn, Poland; ${ }^{b}$ Department of Chemistry, University of Leuven, \\ Celestijnenlaan 200F B-3001 Leuven, Belgium
}


A

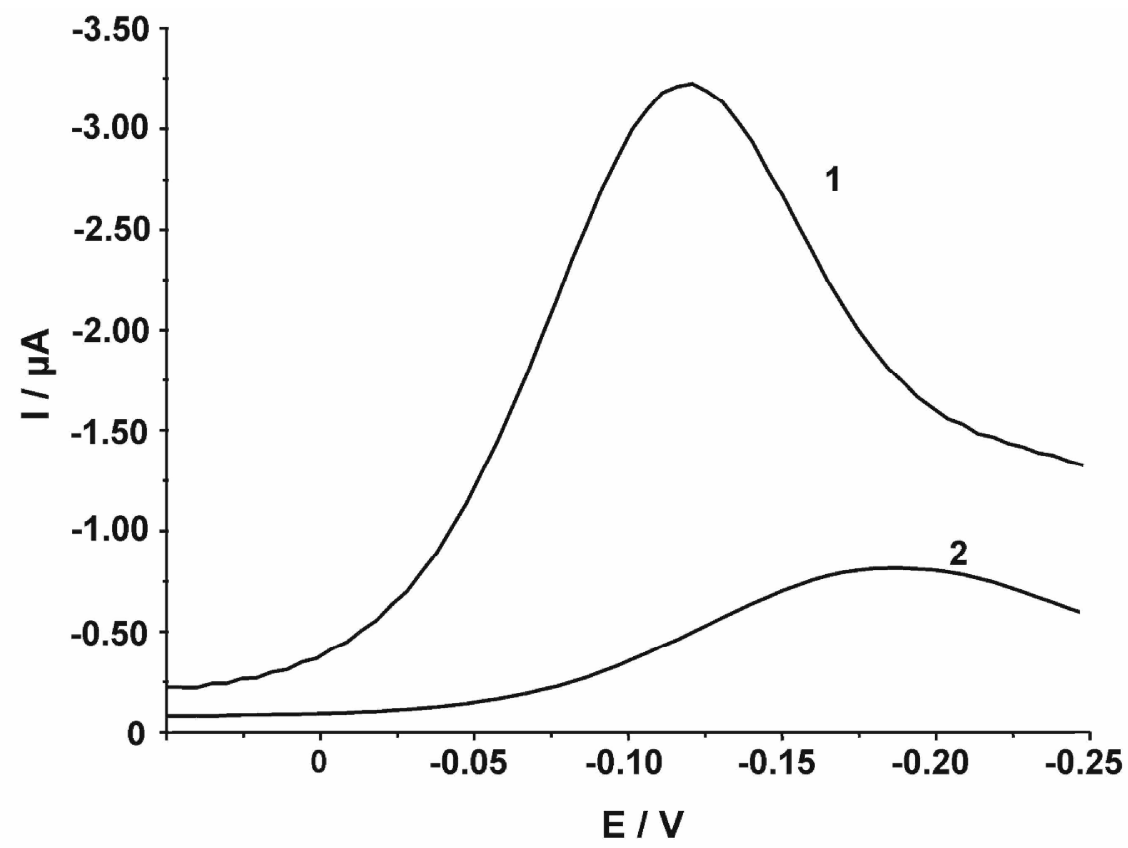

B

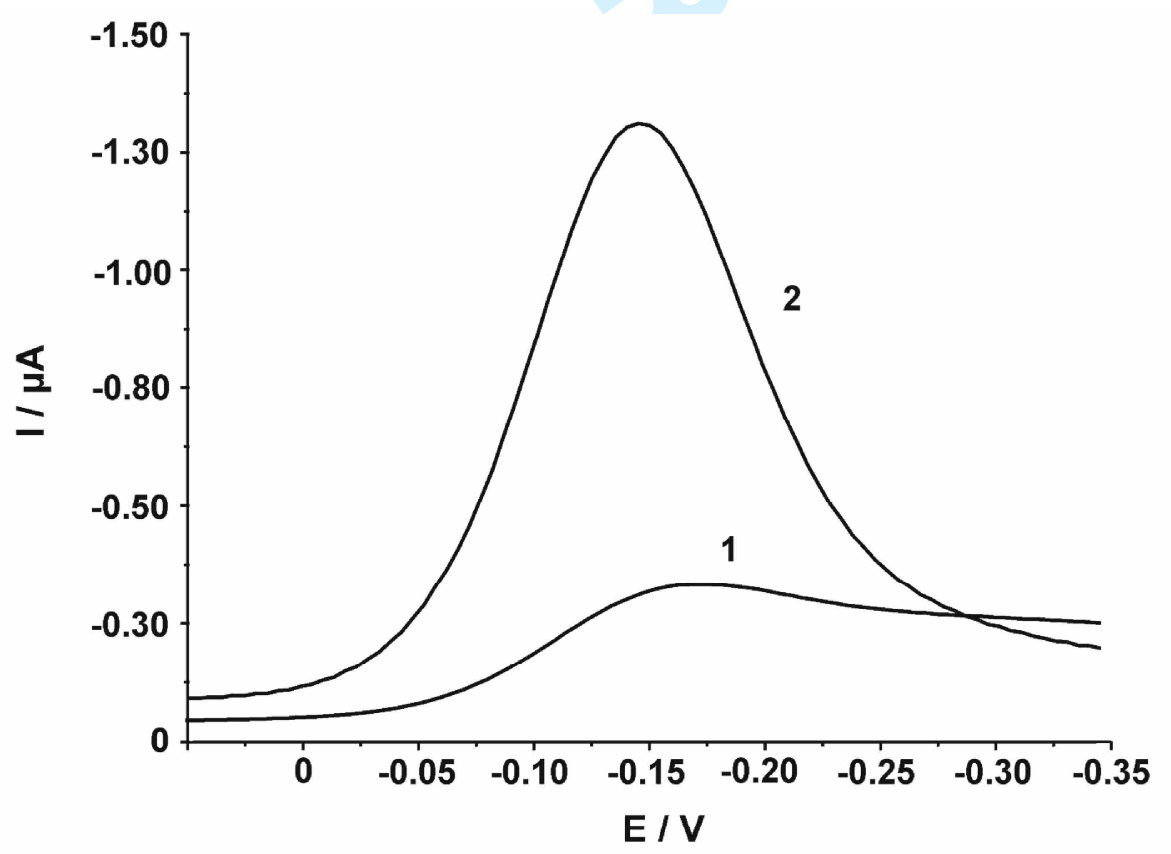

Figure 1. The OSWV curves for $\left[\mathrm{Ru}\left(\mathrm{NH}_{3}\right)_{6}\right]^{3+}$ in $0.01 \mathrm{M} \mathrm{KNO}_{3} \mathrm{pH}=5.0$ measured for gold electrodes modified by (A) embedment type of modification, curve 1: dedecanethiol, 2: dodecanethiol and receptor 2; (B) covalent type of modification, curve 1: dedecanethiol, 2: dodecanethiol and receptor 1. 


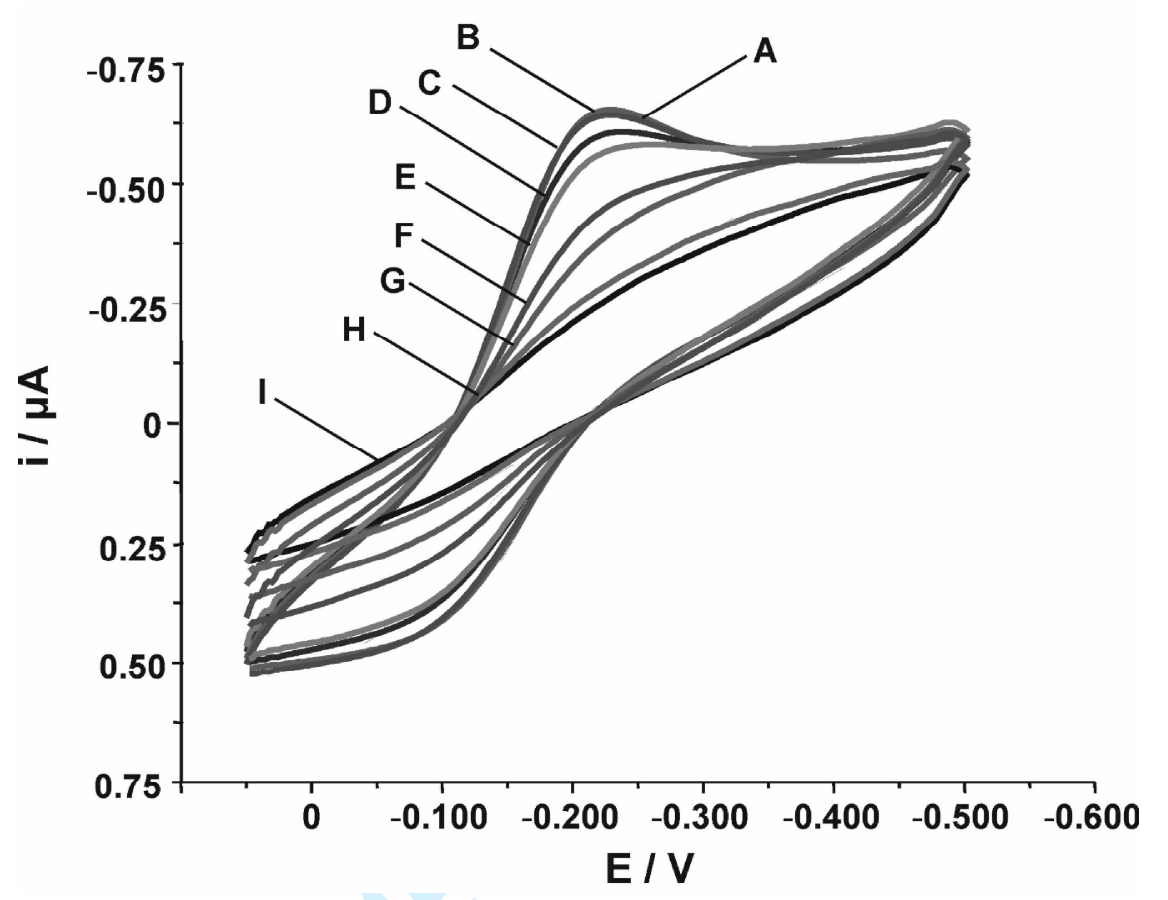

Figure 2. The $\mathrm{CV}$ curves for $\left[\mathrm{Ru}\left(\mathrm{NH}_{3}\right)_{6}\right]^{3+}$ measured in the presence of various concentrations of acrylic acid. Covalent type of modification. The electrolyte composition: $0.01 \mathrm{M} \mathrm{KNO}_{3}$, $\mathrm{pH}=5.0,0.1 \mathrm{mM}\left[\mathrm{Ru}\left(\mathrm{NH}_{3}\right)_{6}\right]^{3+}$. Step potential: $5 \mathrm{mV}$, square-wave frequency $100 \mathrm{~Hz}$, and square-wave amplitude $25 \mathrm{mV}$. The concentration of analyte was, as follows: (A) 0 , (B) $1.0 \times$ $10^{-6}$, (C) $1.0 \times 10^{-5}$, (D) $2.5 \times 10^{-5}$, (E) $5.0 \times 10^{-5}$, (F) $1.0 \times 10^{-4}$, (G) $2.5 \times 10^{-4}$, (H) $5.0 \times 10^{-4}$, (I) $1.0 \times 10^{-3} \mathrm{M}$. 


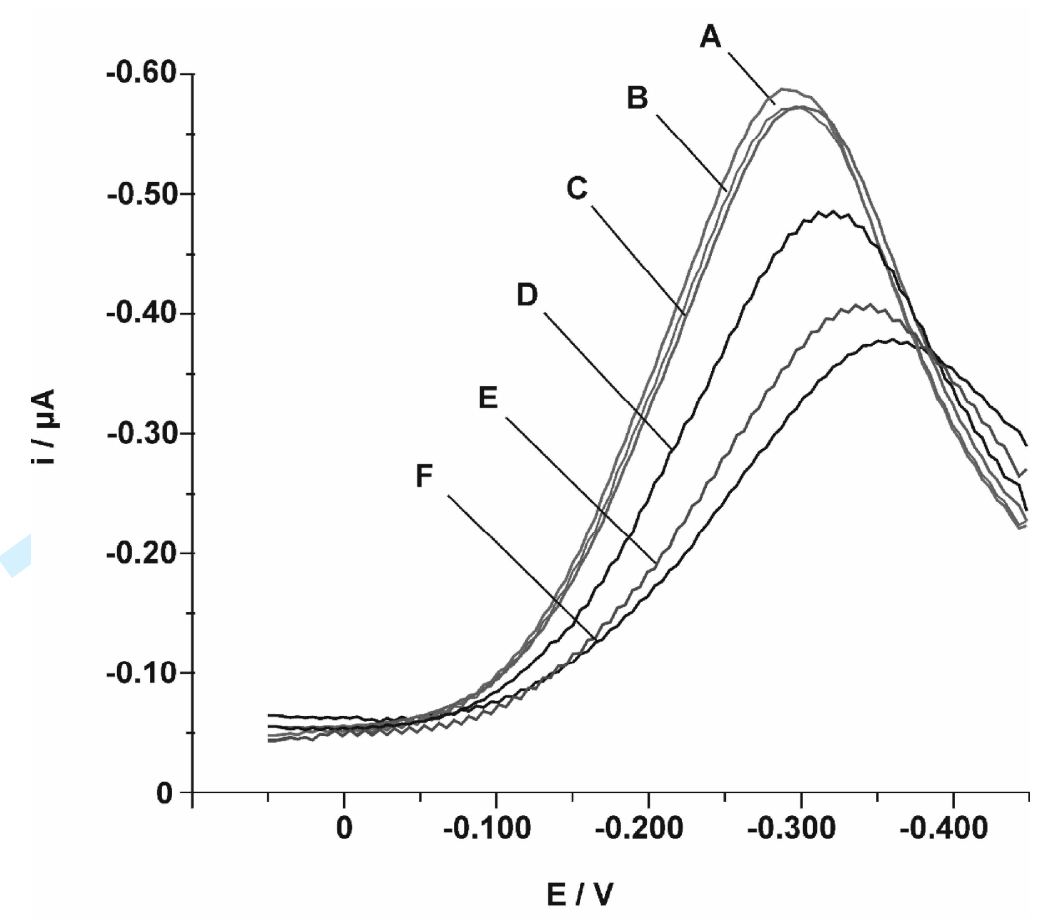

Figure 3. The OSWV curves measured with electrodes modified by embedment technique with receptor 2 in the presence of various concentrations of acrylic acid. For electrolyte composition and measuring conditions see Figure 4. The concentration of analyte was, as follows: A) 0 , (B) $1.0 \times 10^{-6}$, (C) $1.0 \times 10^{-5}$, (D) $1.0 \times 10^{-4}$, (E) $1.0 \times 10^{-3}$, (F) $1.0 \times 10^{-2} \mathrm{M}$. 


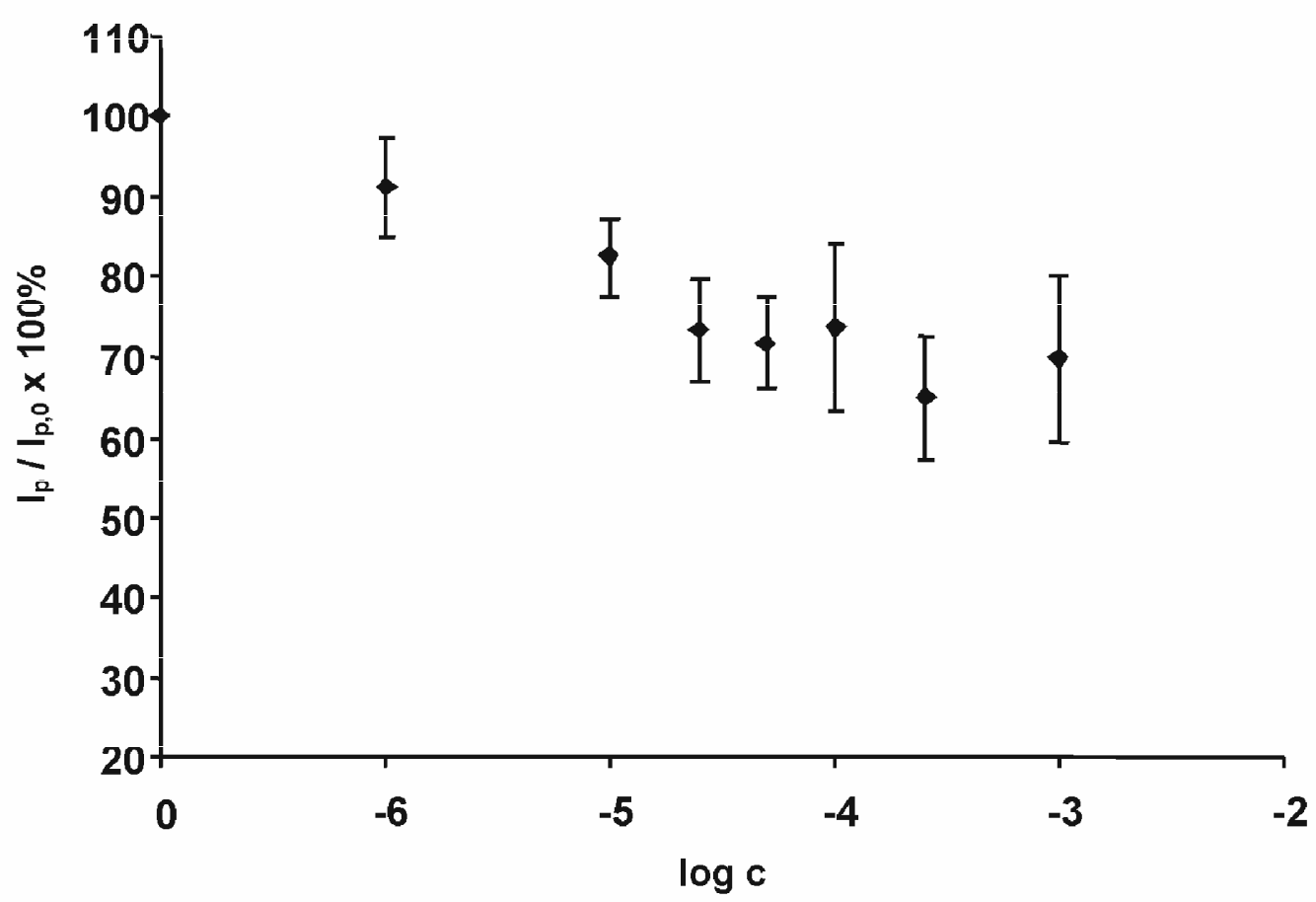

Figure 4. The ratio of OSWV peak current in the presence of different concentration of acrylic acid $\left(\mathrm{I}_{\mathrm{p}}\right)$ to that in the absence of acrylic acid $\left(\mathrm{I}_{\mathrm{p}, 0}\right)$ as a function of the acrylic acid concentration. The electrodes were modified with dodecanethiol. The currents were measured at the peak potential in OSWV curves in the solution with no analyte $\left(\mathrm{E}_{\mathrm{p}, 0}=-210 \mathrm{mV}\right), \underline{\mathrm{n}=3,3.5<\mathrm{SD}<14.3}$ 


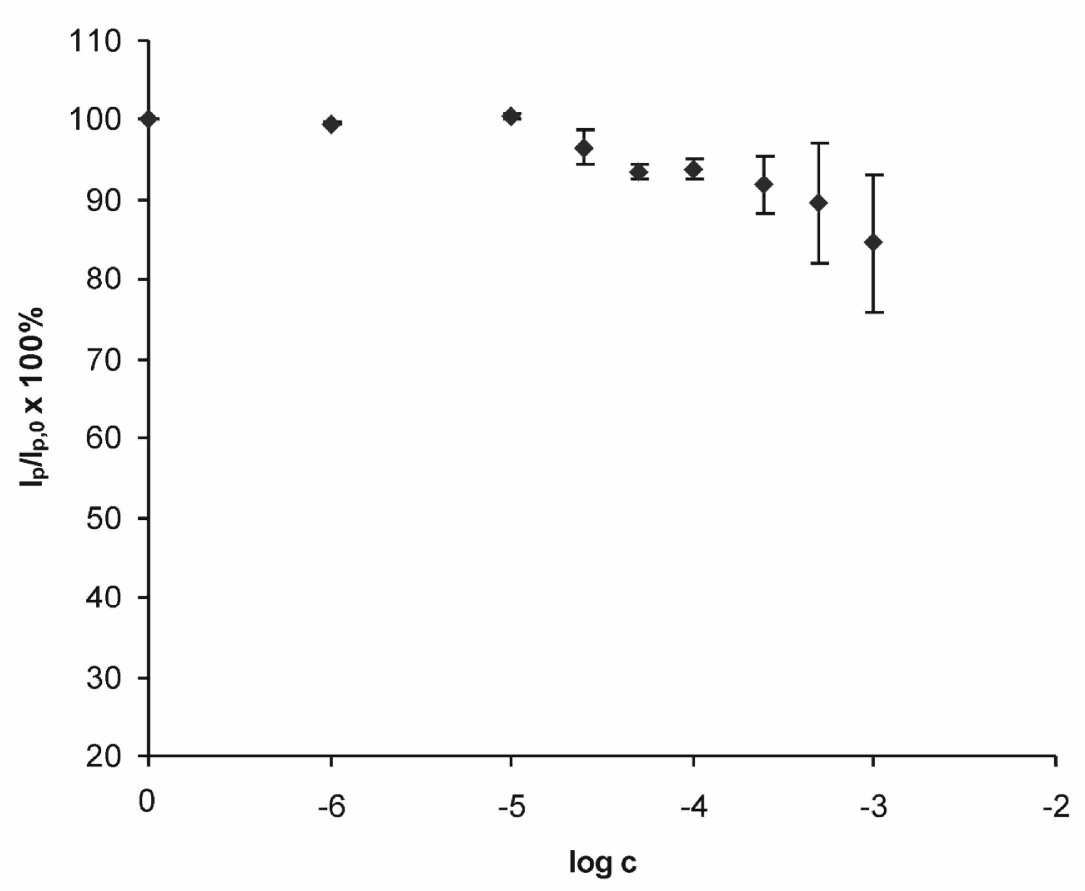

Figure 5. The ratio of OSWV peak current in the presence of different concentration of acrylic acid $\left(I_{p}\right)$ to that in the absence of acrylic acid $\left(I_{p, 0}\right)$ as a function of the acrylic acid concentration. The electrodes were modified by covalent method with receptor 1 in solution $\mathrm{pH}$ 6.25. The currents were measured at the peak potential in OSWV curves in the solution with no analyte $\left(\mathrm{E}_{\mathrm{p}, 0}=-177 \mathrm{mV}\right), \mathrm{n}=3,0.2<\mathrm{SD}<8.6$ 


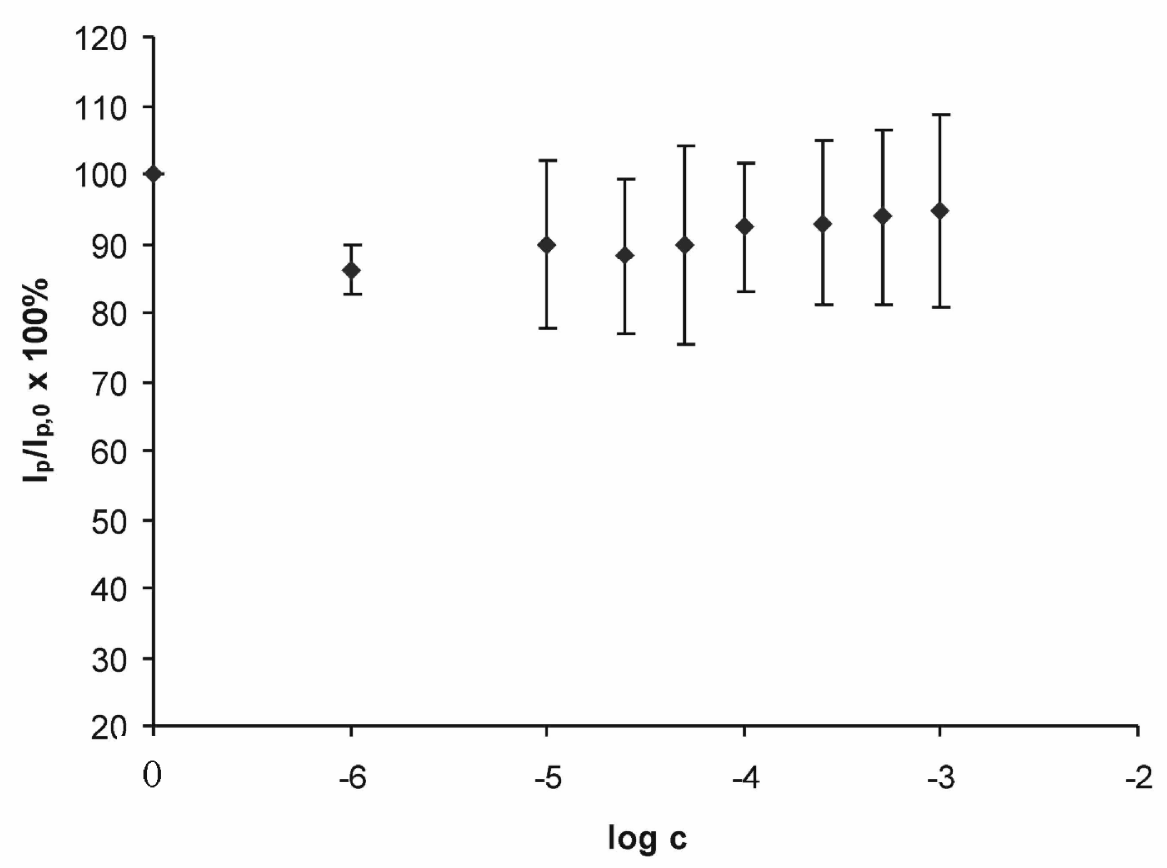

Figure 6. The ratio of OSWV peak current in the presence of different concentration of acrylic acid $\left(I_{p}\right)$ to that in the absence of acrylic acid $\left(I_{p, 0}\right)$ as a function of the acrylic acid concentration for electrodes modified with receptor 3 by embedment type of modification. The currents were measured at the peak potential in OSWV curves in the solution with no analyte $\mathrm{E}_{\mathrm{p}, 0}=-143 \mathrm{mV} . \underline{\mathrm{n}=3,3.5<\mathrm{SD}<14.0}$ 


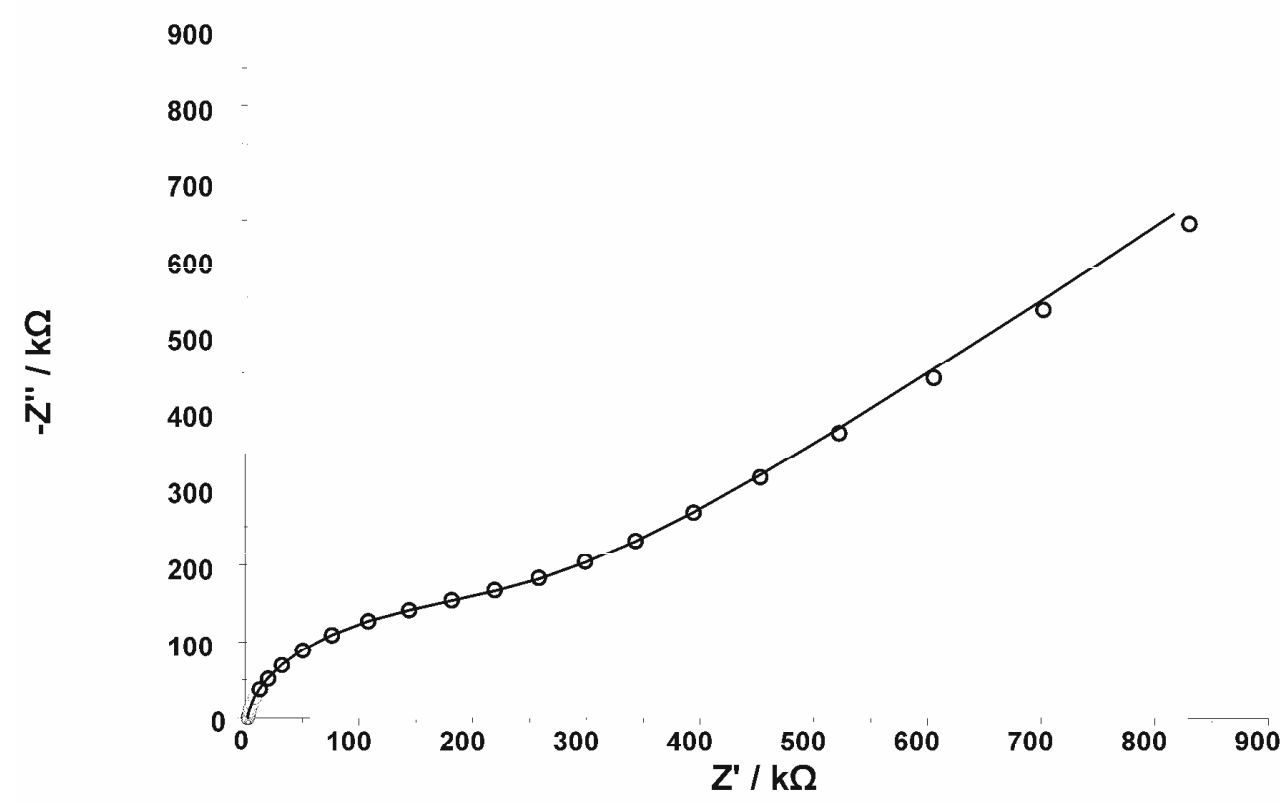

Figure 7. Typical plot of fitting to experimental impedance data obtain for electrode modified with receptor 1 by covalent method using equivalent circuit $\mathrm{R}_{\underline{\mathrm{S}}}\left(\mathrm{Q}_{\mathrm{d} l}\left[\mathrm{R}_{\mathrm{c}} \underline{Z_{\mathrm{w}}}\right]\right)$ showed also on figure 5D. ( $)$ repersent experimental data, $(-)$ represents fitting data. 
Table 1. Characteristic parameters of investigated SAMs obtained from EIS by fitting the spectra with equivalent circuit showed on figure $5 \mathrm{E}$.

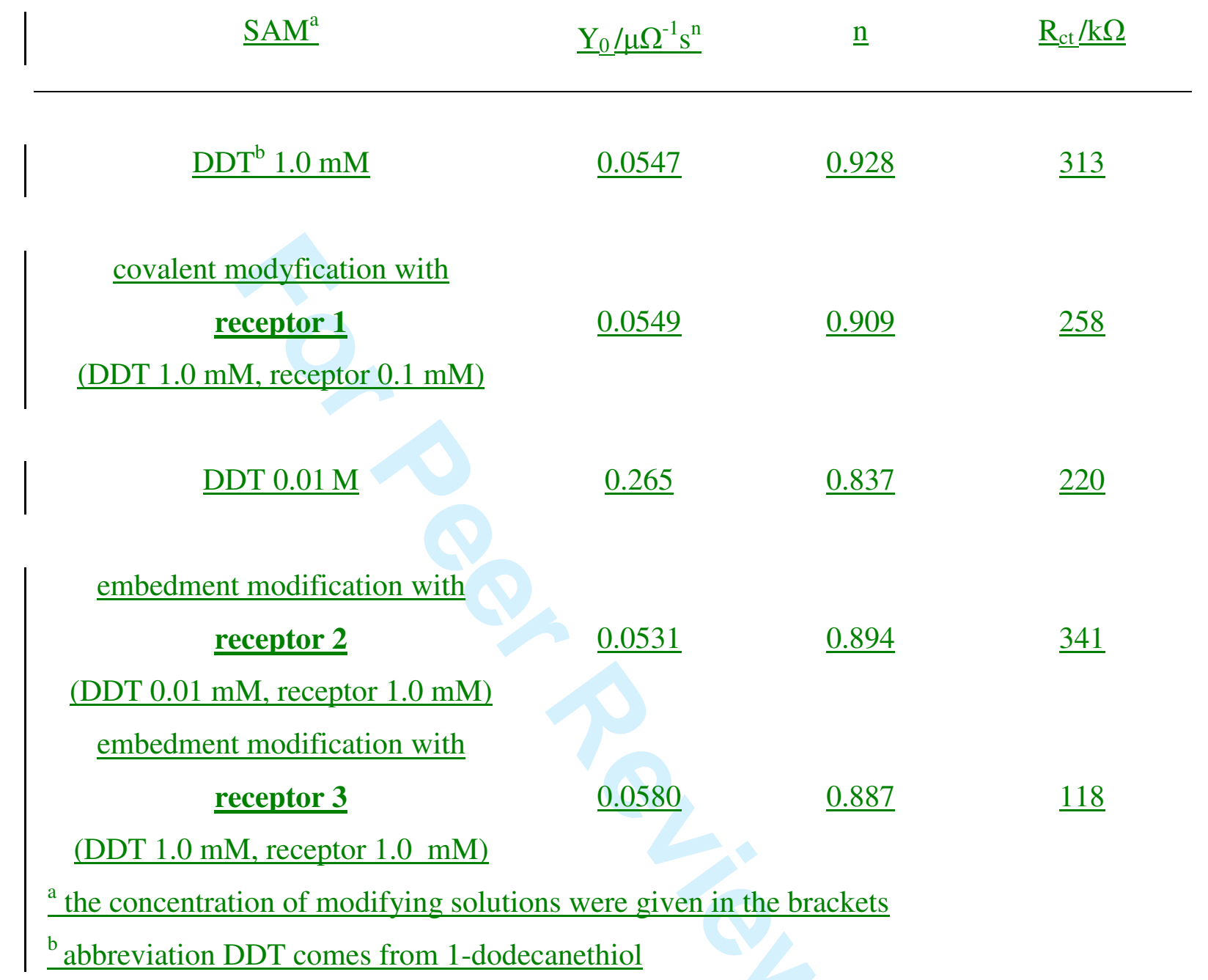

